\title{
HOW WOOD IDENTIFICATION TECHNOLOGIES HELP ENSURE TIMBER LEGALITY IN INDONESIA
}

\author{
KENNY CETERA, ZURAIDAH SAID, FEBRINA DELLAROSE BOER, INDIRA NURUL QOMARIAH, \\ EDI SUPRAPTO, AND SUGENG TRIYANTO
}

\section{EXECUTIVE SUMMARY}

\section{Highlights}

In 2009, Indonesia established the Timber Legality Assurance System (Sistem Verifikasi Legalitas Kayu; SVLK). However, records of misdeclarations of species and origin indicate that illegal logging and the illegal timber trade persist.

- In Indonesia, forest areas are divided into two categories: state forests and nonstate forests. Each category has a different way of reporting in the SVLK. For this paper, we collected information about SVLK implementation in the field from various nongovernmental organization (NGO) reports (state forests) and from field work (nonstate forests).

- This paper explores the potential of wood identification (ID) technologies in generating information about timber species and origin through literature review and correspondence with experts who have experience applying the technologies in illegal logging cases. The ability of these technologies to generate species and origin information is essential in proving the legality of traded timber.

- Our assessment found that Indonesia has a moderately decent capacity for applying wood ID technologies in term of experts and infrastructure. Investing in the development of a wood reference database and laboratory equipment, as well as a legal framework to integrate these technologies into SVLK regulations, would enable the technologies to improve Indonesia's effort to prevent illegal logging and illegal timber trading.

\section{CONTENTS}

Executive Summary

Introduction $\ldots 1$

Methods. 4

An Overview of Timber Traceability Regulations in Indonesia 6

The SVLK 8

Noncompliance Found in Timber from Nonstate

Forests in Klaten District and Yogyakarta Province ......10

An Overview of Wood ID Technologies 15

The Technical Capacity of Wood ID Technologies in Indonesia. 20

Concluding RemarkS.........................................22

Appendix A: Interviews and Correspondence.................25

Abbreviations................................................................26

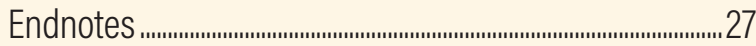

References.

Working Papers contain preliminary research, analysis, findings, and recommendations. They are circulated to stimulate timely discussion and critical feedback and to influence ongoing debate on emerging issues. Working Papers may eventually be published in another form and their content may be revised.

Suggested Citation: Cetera, K., Z. Said, F. Boer, I. Qomariah, E. Suprapto, and S. Triyanto. 2021. "How Wood Identification Technologies Help Ensure Timber Legality in Indonesia." Working Paper. Jakarta, Indonesia: WRI Indonesia. Available online at https://doi.org/10.46830/ wriwp.18.00084 


\section{Context}

Global commodity markets are paying more attention to the sources of the products they are buying by adding green, sustainable, legal, and social standards for products. A recent report by the Food and Agriculture Organization of the United Nations, The State of the World's Forests (FAO and UNEP 2020), shows that since the 1990s, global deforestation has been at a threatening level, endangering not only biodiversity but also the people living in the forests. Setting high standards of legality for timber products is now becoming a concern for markets around the world to halt deforestation and illegal logging activities.

Although Indonesia is one of the world's largest timber exporters, reports suggest that in 2013, illegal logging accounted for 60 percent of all logging in the country (Hoare 2015). In 2009, Indonesia had launched the SVLK to ensure timber legality along the supply chain. The launching had been marked by the Ministry of Forestry (now the Ministry of Environment and Forestry) issuing a regulation governing the SVLK for timber industries to apply the system. In 2013, Indonesia signed a voluntary partnership agreement (VPA) with the European Union to integrate its Forest Law Enforcement, Governance, and Trade (FLEGT) regulation into the SVLK. ${ }^{1}$ In November 2016, the European Union granted Indonesia the right to issue FLEGT licenses to its timber products as long as those timber products abide by SVLK requirements. All timber products that adhere to the SVLK can now enter EU markets without undergoing a strict due diligence process.

\section{Noncompliant and irregular SVLK} implementation in the field has been reported by NGOs and the media (Auriga 2017; Tempo 2018), with the most common practice being the misdeclaration of timber species and origin in timber legality documents. The noncompliance and irregularities stem, in part, from the self-declared way of reporting, the minimum supervision of authorities in the field, and dishonest actors. This can lead to timber laundering: the act of illegal timber being claimed and certified as legal. Timber laundering enables illegal logging activities and the illegal timber trade to continue, jeopardizing the effort to halt deforestation.
To combat all means of timber laundering, previous studies have shown the potential of wood ID technologies to generate timber information (i.e., species and origin) from timber inherited material. Applying wood ID technologies as part of a chain of custody can prevent document falsification and strengthen the SVLK's role in ensuring timber legality along the supply chain, which, in the end, will prevent illegal logging and illegal timber trading.

\section{About This Working Paper}

This working paper elaborates on the reasons why illegal logging activities still exist in Indonesia despite the efforts that have been made by the government. It focuses on the noncompliant and irregular SVLK implementation and traceability control found in the field, which allow timber laundering to occur. This situation puts the SVLK's credibility at risk.

This paper offers recommendations for tackling the misdeclaration of timber information (i.e., species and origin). Wood ID technologies have proved their ability to accurately generate information about timber species and origin and have been used globally in the timber chain of custody and as sciencebased proof in illegal logging cases. Integrating these technologies into the SVLK and the timber chain of custody will strengthen the system's role in ensuring timber legality and preventing illegal logging and illegal timber trading. However, like other kinds of technology, wood ID technologies require supporting infrastructure, laboratory equipment, and databases/ references to operate. Assessing the current state of Indonesia's capacity in applying wood ID technologies is essential to understand at what level application of these technologies can take place. The assessment also helps reveal the enabling conditions needed for these technologies to operate and support efforts to combat illegal logging activities.

This paper aims to provide recommendations to the Government of Indonesia to strengthen the SVLK's role in ensuring timber legality and enforcing the law by applying science-based technologies as criminal evidence for illegal logging cases. For the wider audience, introducing wood ID technologies can give a new perspective on how science can serve as strong evidence against forest crimes such as illegal logging and can halt illegal timber trading. 


\section{Key Findings}

The SVLK aims to ensure the legality of legally certified timber along the supply chain, from the first time the timber is harvested until it enters the market. As a system, if SVLK regulations are thoroughly implemented during each stage of the supply chain, it can trace timber back to its origin. However, findings from our study suggest the opposite. From a study of literature and field work, we found noncompliant SVLK implementation in both state and nonstate forests. The most common noncompliant SVLK implementation involves timber laundering. This situation has put the SVLK's credibility at risk and has violated the legal constituent of V-legal (the SVLK's legal certificate of a timber product).

\section{Timber administration in nonstate forests} is looser since it is only controlled through paperwork, increasing the chances of document falsification. Document falsification is often done to avoid complication of domestic timber administration and for exporting species such as Indonesian rosewood (Dalbergia latifolia; known locally as sonokeling), which would need to comply with the Convention on International Trade in Endangered Species of Wild Fauna and Flora. The misdeclaration of timber species is also done to pay lower forest levies. Forest levies are imposed on timber harvested from state forests according to the commercial value and the region where the timber was harvested.

Science-based tools such as wood ID technologies can identify timber species and origins. Applying these technologies to the timber chain of custody can stop timber laundering by locating any misdeclaration of timber species and origin information found in the legal documentation. Any timber document falsification related to species and origin information can be spotted during any stage of the supply chain, and timber laundering can be avoided. Therefore, illegal timber trading can be prevented, and any indication of illegal logging activities can be identified at an early stage.

This paper briefly elaborates on the different types of wood ID technologies and techniques (wood anatomy, machine vision, mass spectrometry, near-infrared spectroscopy, stable isotope analysis, and deoxyribonucleic acid analysis). Wood anatomy is the most utilized wood ID technique in Indonesia due to a large database of wood samples, and it is supported by adequate expertise. In illegal logging cases, law enforcement frequently uses this method to specify wood specimen up to genus or species level.

To apply the technologies, Indonesia has a decent capacity of wood experts, but it still lacks laboratory equipment and a wood reference database. The Xylarium Bogoriense, part of the Indonesian Ministry of Environment and Forestry, has one of the biggest collections of wood samples in the world to support wood anatomy analysis, but other technologies require a specific wood reference database to support their analysis.

\section{A huge investment is required for the early stage of infrastructure development for wood ID technologies to purchase laboratory equipment and establish a wood reference database for each wood species. Due to the time and expense of such an undertaking, the most significant wood species should be prioritized when establishing a wood reference database. Indicators such as the commercial value, frequency of being reported in illegal logging cases, protection status, species distribution, level of abundancy, and acces- sibility to collect wood samples can be used as the basis for selecting high-priority wood species for the wood reference.}

\section{Recommendations}

These are the steps for tackling illegal logging and the illegal timber trade:

\section{Create a timber species demographic map.} Indonesia's vast forests are distributed across thousands of islands. Having information about the demographic dispersion of timber species will be essential for prioritizing sampling species for the wood reference database. The map can also serve as a first reference when a species or origin has been misdeclared in a timber document.

Strengthen the research capacity and cooperation among scientists and conduct research on the practical applications of wood ID technologies. Support should be given to strengthen existing available tools and techniques and the institutions with the capacity to apply them. Capacity building for wood scientists and law enforcement agencies will need to be compulsory to ensure that these technologies are applied when tackling illegal logging crimes. 
Once technologies are in use, create a protocol to handle indications of illegal timber trading, beginning with "screening" procedures at field checkpoints and continuing through "forensic validation" at a laboratory. At field checkpoints, initial screenings can be made with portable tools that apply wood ID technologies and generate quick results but low certainty. These screenings can give an early indication of illegal timber transport. Further investigation can then apply wood ID technologies with higher certainty that can provide origin information. Guidelines for this step-by-step procedure need to be developed for law enforcement agencies to investigate the illegal timber trade.

- Collect wood samples for a wood reference database. A long-term goal should be to expand the wood reference database, especially for timber species that are heavily traded, highly protected, and illegally logged. This is an essential requirement to implement the "forensic validation" protocol for harnessing more reliable techniques, such as deoxyribonucleic acid analysis and stable isotope analysis.

\section{INTRODUCTION}

The species and origin of timber provide essential information about timber legality. Some species are protected under the Convention on International Trade in Endangered Species of Wild Fauna and Flora (CITES) or under national conservation laws; harvesting these species should be restricted. Information on the origin of timber can indicate whether it was harvested within the permissible area. Misdeclaring timber species and origin can help loggers avoid legal obligations during all stages of business activities, including harvesting, transporting, processing, trading, and exporting.

The objective of a traceability system is to trace timber from its tree stump to the industry where it is processed or exported (FAO 2016). In 2009, Indonesia created a traceability system to track timber along the supply chain, from the forest to the final stages of production. The system differentiates two forest types in its administration: a paper-based system for nonstate forests and an electronic system called the Administration of Forest Information System (Sistem Informasi Penatausahaan Hasil Hutan; SIPUHH) for state forests. SIPUHH provides information on harvested timber as part of Indonesia's Timber Legality Assurance System (Sistem Verifikasi Legalitas Kayu;
SVLK) and is applicable only to timber harvested from state forest concessions, from the point it is harvested to the primary industry where the logs are processed (Box 1).

\section{Box 1. | Land and Forest Governance in Indonesia}

Indonesia divides land into two categories: forest areas and other-use areas (known as areal penggunaan lain; APL). Forest areas are divided into three categories: State forest (hutan negara), administered by the
government through the Ministry of Environment and
Forestry (MoEF)

Nonstate forest (hutan hak), owned by individuals, where land tenure is proved by land certificate

Customary forest (hutan adat), owned communally by a tribe or indigenous community

State forests are divided into three types, based on function:

Conservation forest (hutan konservasi)

Protected forest (hutan lindung)

Production forest (hutan produksi)

Production forests are designated for various types of forest concessions, including the following:

Selective logging (Izin Usaha Pemanfaatan Hasil Hutan Kayu-Hutan Alam; IUPHHK-HA)

Timber plantation (Izin Usaha Pemanfaatan Hasil Hutan Kayu-Hutan Tanaman Industri; IUPHHK-HTI)

Ecosystem restoration (Izin Usaha Pemanfaatan Hasil Hutan Kayu-Restorasi Ekosistem; IUPHHK-RE).

MoEF can issue a special forest concession permit in protected forest areas only in the form of a Borrow-to-Use Permit (Izin Pinjam Pakai Kawasan Hutan; IPPKH).

Nonstate forests are defined as forest areas owned by individuals who have planted timber trees. These individuals are known as timber smallholder farmers. The administrative process for timber harvested from nonstate forests differs from the process for timber harvested from state forests, especially in the upstream chains before the timber enters the primary industry. This forested area is located in APL administrative areas and thus is not under the jurisdiction of MoEF. In principle, smallholders can also cultivate timber in state forest areas, but they need to obtain a permit or license from MoEF to do so.

Sources: a. Article 5 of Indonesia's Law No. 41 of 1999 on Forestry, in conjunction with Constitutional Court Decision No. 35/PUU-X/2012; b. Obidzinski et al. 2014. 


\section{METHODS}

The information and data used in this report were collected by reviewing literature, conducting field visits, and interviewing and corresponding with experts. Information on SVLK implementation in state forests was gathered from reports written by nongovernmental organizations (NGOs) and independent monitors, and information about its implementation in nonstate forests was collected from field visits comprising interviews with actors involved in different stages of the supply chain and government institution staff responsible for monitoring timber movement at the subnational level. The team conducted field visits in Klaten District (Central Java Province) and Yogyakarta Province, where nonstate forest areas and timber industries are abundant, to collect data.

\section{Literature Review}

The literature review included reports of illegal logging activities by NGOs and independent forest monitors, such as reports by the Independent Forest Monitoring Network (Jaringan Pemantau Independen Kehutanan) on noncompliant and irregular SVLK implementation. It also drew on reports of illegal logging and timber laundering by environmental media, such as Mongabay and Tempo. SVLK-related regulations were studied to understand how the system works, how the Indonesian government regulates it, and how loopholes allow timber crimes to occur.

\section{Field Visits and Interviews}

Field visits were undertaken in Yogyakarta Province and in Klaten District to observe timber traceability and compliance with SVLK implementation. During field visits, the report team mapped the actors involved in the timber supply chains, interviewed them, and visited several timber trading points along the supply chain and relevant government institutions to gather information. The team interviewed 24 people in the supply chain, including 3 farmers, 5 traders, 2 people who worked at sawmills or in primary industries, 5 timber exporters or people who worked in secondary industries, 2 people who worked at certification bodies, 4 subnational-level officials from the Ministry of Environment and Forestry (MoEF), 1 subnational-level official from the Ministry of Industry, and 2 timber supply chain researchers from Gadjah Mada University in Yogyakarta Province.
To learn how wood identification (ID) technologies were used as science-based evidence in court, the team carried out interviews with various wood experts (see Appendix A). The purpose of the interviews was to obtain information about the technical capacity of wood experts to conduct the analysis and the availability of laboratory equipment and wood sample references necessary for the technologies. They also provided information about how the technologies could be used in illegal logging cases and whether they were accepted as science-based evidence in court.

The focus was on two timber species: Dalbergia latifolia (Indonesian rosewood, known locally as sonokeling) and Tectona grandis (teak). Dalbergia latifolia is listed in Appendix II of CITES (see Box 1), meaning that trade should be strictly controlled. Teak is highly traded and used to make furniture, especially on Java Island. This study focuses on these species because of their significance in Java's furniture industry and the concerns about their sustainability. The following questions were asked during the interviews:

How familiar are you with traceability regulations and SVLK requirements?

For rosewood logs or products, how familiar are you with the requirements of the Domestic Transport of Plants and Animals Letter (Surat Angkut Tanaman dan Satwa Dalam Negeri; SATS-DN) and the Overseas Transport of Plants and Animals Letter (Surat Angkut Tanaman dan Satwa Luar Negeri; SATS-LN)?

- Do you regularly check the validity of information as stated on the transport documents?

- For downstream industries, are you SVLK certified? If not, can you still export goods?

- Is there any internal control mechanism at your institution to verify the traceability information on paperwork?

- How do government officials and/or certification bodies enforce the traceability regulation?

For certification bodies, do you find common irregularities pertaining to traceability requirements during audits or surveillance? What kind of irregularities?

This working paper elaborates on the issues of improper SVLK implementation that lead to persistent illegal logging activities and the illegal timber trade. It 
focuses on two forest types and suggests that wood ID technologies be applied to tackle these issues. Specific attention is given to traceability control in nonstate forests, where field reporting is limited and loosely controlled, and to the readiness of applying wood ID technologies in Indonesia to improve the timber chain of custody and to use science-based technologies to enforce forest law.

\section{AN OVERVIEW OF TIMBBER TRACEABILITY REGULATIONS IN INDONESIA}

According to MoEF regulation, forest administration was differentiated between state forests and nonstate forests. The traceability system for timber from nonstate forests is modest compared to the one for state forests, and it does not require reports to be submitted to SIPUHH online. A landownership certificate can act as legal proof of harvested timber, and a geo-location record of a tree stump is not necessary. Because land tenure in nonstate forests is held by individuals, harvesting plans are not required and the volume of timber harvested is not strictly controlled. Self-declared documentation and a document checklist are the bases of timber traceability and administration. To comply with regulations, timber industries-middle and downstream chains-are required to declare at different stages of the supply chain the species and origin of timber harvested from both state and nonstate forests. Some examples are presented in Table 1.

\section{State Forests}

Before tree harvesting can commence in a state forest, a concessionaire's General Work Plan (Rencana Kerja Umum; RKU) and Annual Work Plan (Rencana Kerja Tahunan; RKT) must be approved by the Directorate General of Sustainable Production Forest Management (Direktorat Jendral Pengelolaan Hutan Produksi Lestari; Dirjen PHPL) under MoEF. The RKU and RKT are used to control the volume and species of timber harvested from the concession area, as reported by the concessionaire through SIPUHH online. During the preparation of the RKT, the concessionaire is required to submit a Timber Cruising Report (Laporan Hasil Cruising) and to upload all information attached to the log barcode of each tree to be harvested before timber harvesting starts. The log barcode contains the block number, tree number, tree species, log diameter, branch-free height, and tree location. The tree location contains the coordinate information from which each timber can be traced back to its stump. A barcode corresponding to the information in the SIPUHH database should be attached to every log.

During harvesting, the concessionaire must incorporate data on harvested trees, including species and volume, to SIPUHH online. The information is used to calculate forest levies, including the Forest Resource Provision (Provisi Sumberdaya Hutan; PSDH) and Reforestation Fund (Dana Reboisasi). Concessionaires cannot procure transport documents for logs (Timber Legality Letter

Table 1 | Reporting Requirements for Species and Origin of Timber in Indonesia, by Type of Forest and Stage in Supply Chain

STAGES IN SUPPLY CHAIN

State forest concessions (selective logging forest

concession; timber plantation)-upstream chain

Processing industries-downstream chain

Nonstate forest-upstream chain

\section{REPORTING REQUIREMENT}

- Declaration and inventory of protected and nonprotected species to obtain approval of annual harvest plan

- Declaration of timber species or commercial name during harvesting report as basis for forest levies (Forest Resource Provision [Provisi Sumberdaya Hutan] and Restoration Fund [Dana Reboisasi])

- Declaration of timber species (or commercial name) and origin in the Transport Document (Nota Angkutan) and Continued Transport Document (Nota Angkutan Lanjutan)

- Declaration of species and harvesting countries on the application of $\mathrm{V}$-legal ${ }^{2}$ document for exporting 
[Surat Keterangan Sahnya Hasil Hutan Kayu Bulat]) through SIPUHH online if they have not paid the levies. Transporting timber outside the concession area without transport documents constitutes a forest crime under Indonesia's Law No. 41 of 1999 on Forestry.

In addition, Dirjen PHPL checks whether the volume of timber reported on the SIPUHH website is in line with the approved RKT. The system automatically freezes the concessionaire's account once the timber volume reported reaches the quota allowed to be harvested; hence, the concessionaire will be unable to input any information into the system, and timber harvesting cannot take place. Even if trees are cut down despite having reached the annual limit, the concessionaire cannot obtain transport documents with a frozen account. The Transport Document (Nota Angkutan) is proof of timber legality that is checked in the field, and its absence is considered a criminal offense.

\section{Nonstate Forests}

Nonstate forest timber is administered through selfdeclared documents known as the Transport Document and the Continued Transport Document (Nota Angkutan Lanjutan). These two documents act as proof of timber legality, called the Supplier's Declaration of Conformity (Deklarasi Kesesuaian Pemasok; DKP). This declaration holds the same legal recognition as the Sustainable Production Forest Management Certification (Sertifikat Pengelolaan Hutan Produksi Lestari; S-PHPL) and the Timber Legality Certification (Sertifikat Legalitas Kayu; S-LK) in state forests.

Unlike a forest concession holder, timber farmers do not need to make any plan before harvesting their timber, do not need approval to harvest their timber, and do not report the harvested timber into any system. Farmers need to attach a copy of their land certificate as proof of timber origin and issue the Transport Document to the timber trader when they sell the timber. When the trader receives the timber, he or she must deactivate the Transport Document and issue the Continued Transport Document to transport the timber to the next buyer or primary industry, which later will deactivate this Continued Transport Document and issue a new Continued Transport Document to transport the timber to the next link in the chain. This step can recur several times depending on the length of the chain. When the timber reaches the secondary industry, the industry needs to issue a DKP document to get the timber legally certified. The DKP document and the V-legal certification are required to obtain the export document, which is administered and issued by MoEF. The DKP is not required to be submitted to MoEF for domestic trade; hence, data for national timber trading are not well recorded.

In both Klaten District and Yogyakarta Province, where we did field work, there are many small- and medium-scale industries that did not document their source of timber. This situation has caused difficulty for downstream exporting companies, which receive halfprocessed products from them, to provide legal proof of timber. For this reason, the companies prefer to exclude this type of industry from their supply chain to comply with international market standards (EU FLEGT Facility 2019).

Table 2 summarizes the different treatments applied to the different types of forests. Timber administration in nonstate forests is pretty modest compared to administration in state forests (selective logging forest concession and timber plantation), which results in document falsification and leads to timber laundering. Despite a better online system that supports state forest timber administration, document falsification still occurs. 
Table 2 | Regulations Governing the Administration of Timber Harvesting and the Timber Supply Chain in Indonesia, by Type of Forest and Concession

\begin{tabular}{|c|c|c|c|}
\hline & $\begin{array}{l}\text { SELECTIVE LOGGING FOREST } \\
\text { CONCESSIONS IN STATE FORESTS } \\
\text { (IUPHHK-HA) }\end{array}$ & $\begin{array}{l}\text { TIMBER PLANTATIONS IN STATE } \\
\text { FORESTS (IUPHHK-HTI AND SOCIAL } \\
\text { FORESTRY SCHEME) }\end{array}$ & NONSTATE FORESTS \\
\hline Legal basis & $\begin{array}{l}\text { Ministry of Environment and } \\
\text { Forestry (MoEF) Regulation No. P.66/ } \\
\text { MENLHK/SETJEN/KUM.1/10/2019 }\end{array}$ & $\begin{array}{l}\text { MoEF Regulation No. P.67/MENLHK/ } \\
\text { SETJEN/KUM.1/10/2019 }\end{array}$ & $\begin{array}{l}\text { MoEF Regulation No. P.48/MENLHK/ } \\
\text { SETJEN/KUM.1/8/2017 and MoEF } \\
\text { Regulation No. P.85/MENLHK/ } \\
\text { SETJEN/KUM.1/11/2016 }\end{array}$ \\
\hline $\begin{array}{l}\text { Required legal docu- } \\
\text { ments }\end{array}$ & $\begin{array}{l}\text { - Timber Cruising Report (Laporan } \\
\text { Hasil Cruising) } \\
\text { - } \text { Measurement Book (Buku Ukur) } \\
\text { - } \text { Timber Production Report } \\
\text { (Laporan Hasil Produksi) } \\
\text { - } \text { Timber Legality Letter (Surat } \\
\text { Keterangan Sahnya Hasil Hutan) } \\
\text { - Transport Document (Nota } \\
\text { - Angkutan) } \\
\text { - Company Document (Nota } \\
\text { Perusahaan) }\end{array}$ & $\begin{array}{l}\text { - Timber Cruising Report (Laporan } \\
\text { Hasil Cruising) } \\
\text { - } \text { Measurement Book (Buku Ukur) } \\
\text { - } \text { Timber Production Report } \\
\text { (Laporan Hasil Produksi) } \\
\text { - } \text { Timber Legality Letter (Surat } \\
\text { Keterangan Sahnya Hasil Hutan) } \\
\text { - Transport Document (Nota } \\
\text { - Angkutan) } \\
\text { - } \text { Company Document (Nota } \\
\text { Perusahaan) }\end{array}$ & $\begin{array}{l}\text { Transport Document (Nota } \\
\text { Angkutan), applicable as } \\
\text { Supplier's Declaration } \\
\text { of Conformity (Deklarasi } \\
\text { Kesesuaian Pemasok; DKP) }\end{array}$ \\
\hline Reporting method & $\begin{array}{l}\text { Self-declaration through the } \\
\text { Administration of Forest Information } \\
\text { System (Sistem Informasi } \\
\text { Penatausahaan Hasil Hutan; } \\
\text { SIPUHH) website }\end{array}$ & $\begin{array}{l}\text { Self-declaration through the SIPUHH } \\
\text { website }\end{array}$ & $\begin{array}{l}\text { Submission of DKP and Nota } \\
\text { Angkutan to Forestry Agency Office } \\
\text { at the provincial level }\end{array}$ \\
\hline $\begin{array}{l}\text { Applied timber } \\
\text { tracking technology }\end{array}$ & $\begin{array}{l}\text { Online tracking system with barcode } \\
\text { attached to all logs }\end{array}$ & $\begin{array}{l}\text { Online tracking system with barcode } \\
\text { required for some tree species, } \\
\text { depending on species and log size }\end{array}$ & None \\
\hline $\begin{array}{l}\text { Payment of Forest } \\
\text { Resource Provision } \\
\text { (Provisi Sumberdaya } \\
\text { Hutan; }\end{array}$ & Yes & PSDH only & $\begin{array}{l}\text { No, unless the timber grows } \\
\text { naturally }\end{array}$ \\
\hline
\end{tabular}

Source: WRI authors

\section{THE SVLK}

Indonesia's SVLK is a legality assurance system that ensures the compliance of businesses to prevailing laws and regulations regarding the timber trade, including the timber traceability regulation discussed above. The concept behind SVLK certification is similar to that of the Forest Stewardship Council (FSC) and the Programme for the Endorsement of Forest Certification (PEFC): timber harvesting and processing should meet legality and sustainability standards set by the certification scheme. In return, benefits gained from being certified include premium prices (FSC and PEFC) and access to specific markets (the EU and Australian markets for the SVLK). Unlike the FSC and the PEFC, however, which work on a voluntary basis, SVLK certification is mandatory for all concessionaires and industries involved in the timber supply chain. At the initial phase of this study, the SVLK was regulated under MoEF Regulation No. P.30/MENLHK/SETJEN/ PHPL.3/3/2016, which recently was updated to MoEF Regulation No. P.21/MENLHK/SETJEN/ KUM.1/10/2020. This paper does not review each principle under the earlier MoEF regulation but instead discusses only the relevant certification and traceability control parts of the SVLK, which are not different in the two regulations. 
The SVLK comprises three components:

\section{The S-PHPL}

\section{The S-LK}

\section{The DKP}

In principle, S-PHPL certification is obligatory for any concessionaire whose forest concession area is in a state forest, whereas S-LK certification is mandatory for downstream industries (primary industry, secondary industry, and exporters) receiving timber from both types of forests. The certifications assess different areas: legal sourcing, timber production, environmental and social impact, and labor safety. Legal certification, in the form of the V-legal document, is issued by a certification body-a third-party company whose license to certify is accredited by the National Accreditation Committee (Komite Akreditasi Nasional). The certification body conducts periodical surveillance to ensure that all standards are met by the certified company. If noncompliance and irregularities are found during the surveillance, the certification body will freeze the V-legal certification held by the company. In the European Union's Forest Law Enforcement, Governance, and Trade (FLEGT) VPA framework, independent monitors-civil society organizations or local initiatives independently monitoring SVLK implementationplay a vital role in reporting irregularities and noncompliance for the certified company, from which the certification body can verify and freeze the certificate if found to be true.

The DKP is legal proof of timber for both logs and halfprocessed products from nonstate forests. Based on the traceability regulation, two documents-the Transport Document and the Continued Transport Document, along with the land certificate or other landownership documents - are valid transport documents that apply as the DKP.

The Transport Document is issued for logs transported from forests to designated log ponds and/or primary industries. Once the logs reach the registered log pond and/or primary industry, the Continued Transport Document is issued to transport the logs or halfprocessed timber to the next destination. Any timber harvested from a nonstate forest that is accompanied by the Transport Document is considered legal as long as the farmer who owns the tree can show proof of land tenure (in the form of a land certificate, for example).

Large downstream industries collecting timber from farmers must obtain the S-LK because the Transport Document only can be used by farmers and small craftspeople within upstream supply chains. In principle, timber industries receiving the Transport Document must verify the timber sources as stated on the document. In practice, this mandate is often ignored because noncompliance is not sanctioned.

Under the SVLK, the export of timber can be done only by legally certified companies, which have met all legality requirements, and in the form of final or half-processed timber products, not wood logs. V-legal is an export document, attached to a timber product, that affirms that the product has met all legality requirements according to Indonesian law. V-legal applies as a FLEGT license providing access to the EU market without due diligence.

At this time, the Indonesian traceability system is not yet fully electronic based; the electronic system and barcode have been applied at state forests, but nonstate forests still use paper-based controls. In terms of SVLK requirements, smallholders from nonstate forests were also exempted from SVLK certification and can selfdeclare their conformity (through the DKP) to satisfy legality requirements. If this different treatment is misused by dishonest actors, it can create a loophole that allows illegal timber trading, such as claiming illegal timber from state forests using nonstate forest documentation. Some reports revealed that falsification of transport documents is the most common practice for smuggling timber. For instance, Mongabay (Asrida 2018) reported that five companies used fake documents and barcodes to transport 81 containers of illegal wood logs from Nabire, Papua Province, to Surabaya, East Java Province. The SIPUHH database showed that the companies transporting the logs were not the companies holding the concession permits that corresponded to the logs' barcodes. These are some examples of common types of document falsification:

\section{Misdeclaration of timber origin. A report} by Telapak and the Environmental Investigation Agency (2005) found that a company violated the Indonesian export ban on wood logs by claiming that Indonesian merbau timber from Papua was from Papua New Guinea, which allowed the export of wood logs and unprocessed wood.

- Misdeclaration of timber species. A company tried to reduce its forest levies on timber harvested in state forests by claiming that the species harvested were less expensive than they actually were. This idea is hypothetical but very possible. Indonesia applies different levies to different types of timber (based on species and origin), which depends on timber quality and the level of trade restriction. 
A recent article (Liu et al. 2020) showed that a big discrepancy of data for Indonesian timber exported to China-as reported by Indonesia's government and as recorded by China's government-resulted from misclassification and misreporting.

\section{- Timber harvesting outside legal boundar-}

ies. Timber was harvested outside legal boundaries, including in conservation and protected forests, outside the concession area, and outside the approved RKT boundary for the year (these include the case of Adelin Lis in 2009 and the concession holder company Merbau Palalawan Lestari in 2013).

Timber laundering. Certified processed-wood manufacturers reported timber be legal although some sources were unclear (Ichwan et al. 2017; Jong 2019).

All of the document falsifications mentioned above came from media and NGO reports on the modus operandi for illegal logging in state forests. In contrast, illegal logging activities and noncompliance with SVLK implementation in nonstate forests are rarely documented. Hence, the team conducted field visits in Klaten District and Yogyakarta Province to observe areas where nonforest areas are widespread and timber industries are plenty. The next section of this paper consists of our findings from the field visits.

\section{NONCOMPLIANCE FOUND IN TIMBER FROM NONSTATE FORESTS IN KLATEN DISTRICT AND YOGYAKARTA PROVINCE}

From field observations of SVLK implementation in nonstate forests, locally known as hutan rakyat, and the harvested timber supply chains in Klaten District and Yogyakarta Province, we found noncompliance and irregularities that may put SVLK credibility at risk. Interviews were carried out to target upstream chain actors (farmers and timber traders) in Yogyakarta and downstream chain actors (sawmills and processing industries) in Klaten. The snowball interview method was applied to identify potential interviewees who represented different actors in different stages of the supply chain.

\section{MoEF Regulation No. P.21/MENLHK/SETJEN/}

KUM.1/4/2019 defines a nonstate forest as a forest that is located on the land with legitimate title. In practice, a location that is characterized by privately owned forest and has land tenure proved by a legitimate land certificate is termed a nonstate forest (Suprapto 2010). This category of forestland was the result of a past project to rehabilitate degraded land - uncultivated land with minimal or no vegetation cover that can lead to desertification - by planting drought-resistant trees such as teak and rosewood. After some years, the land formed forests, from which timber was harvested and sold by the landowner as a commodity. At first, the selling was done occasionally to get instant income for individual needs (such as school fees or house construction, for example).

This practice changed as demand for timber increased during the late 1990s; hence, more and more timber is harvested from nonstate forests to meet industrial demand. In 2000, the timber supply from nonstate forests reached approximately 900,000 cubic meters $\left(\mathrm{m}^{3}\right)$ a year, equal to 11 percent of the timber supplied to industry on Java Island (Suprapto 2010). Nonstate forest timber production could reach up to 1.4 million $\mathrm{m}^{3}$ annually, greatly exceeding annual production of Perhutani - a state-owned enterprise managing timber plantations on Java Island — of $300,000 \mathrm{~m}^{3}$ (Obidzinki et al. 2014).

This study chose the supply chain of timber sourced from nonstate forests because MoEF plays a small role in controlling its administration through a simple document checklist and self-declaration, which are prone to fraud. Teak and rosewood were selected because those are the main commodities traded in nonstate forests, and they represent the different complications of timber administration for export products. Teak grows naturally in Java, Madura, Kangean, Southeast Sulawesi, Muna, and Buton (Siregar 2005). It can now be found in most regions of Indonesia. Indonesian rosewood is nonnative to Indonesia; it came from South Asia. It was introduced to Indonesia during the period of Dutch colonialism and was planted mainly in Central Java and East Java (Directorate of Biodiversity Conservation 2017). Since January 2017, rosewood, like other species under the Dalbergia genus, has been listed in Appendix II of CITES (Box 2). This designation leads to some restrictions and additional administrative procedures to export the timber.

Both teak and rosewood have been linked to the crossborder illegal timber trade (Erickson-Davis 2017; Neumeister and Cooper 2019; Taylor et al. 2012). Unlike in state forests, the inventory of standing trees in nonstate forests is not well recorded. Although some inventory attempts have been made by MoEF at the subnational level as well as by Perhutani and civil society organizations, the records were scattered. Despite being listed in Appendix II of CITES and categorized as "Vulnerable" in the International Union 
for Conservation of Nature's Red List, the Indonesian Institute of Science (Lembaga Ilmu Pengetahuan Indonesia; LIPI) — which is responsible for assessing the protection status of Indonesia's fauna and flora species - claims that rosewood is not at the endangered status because it is nonnative to Indonesia and is classified as a plantation commodity (Directorate of Biodiversity Conservation 2017). As a species listed in Appendix II of CITES, exporting rosewood creates more complications in documentation compared to exporting teak (Table 3).

As mentioned above, the Transport Document and Continued Transport Document apply as transport documents and proof of timber legality (DKP). Both documents contain information such as source and destination, volume, and the commercial name of the timber as well as the document's expiry date. According to SVLK regulation, the Transport Document is issued by the first timber seller - in this case, farmers - to accompany the sold timber transported from their land to the first destination or trader. The Continued Transport Document is issued by timber traders or sawmills - who receive timber from farmers-to transport the timber from their place to the next destination, and so forth. This process of issuing Continued Transport Documents, with different information contained, can recur several times if the supply chain is long.

\section{Box 2. Appendixes to the Convention on International Trade in Endangered Species of Wild Fauna and Flora}

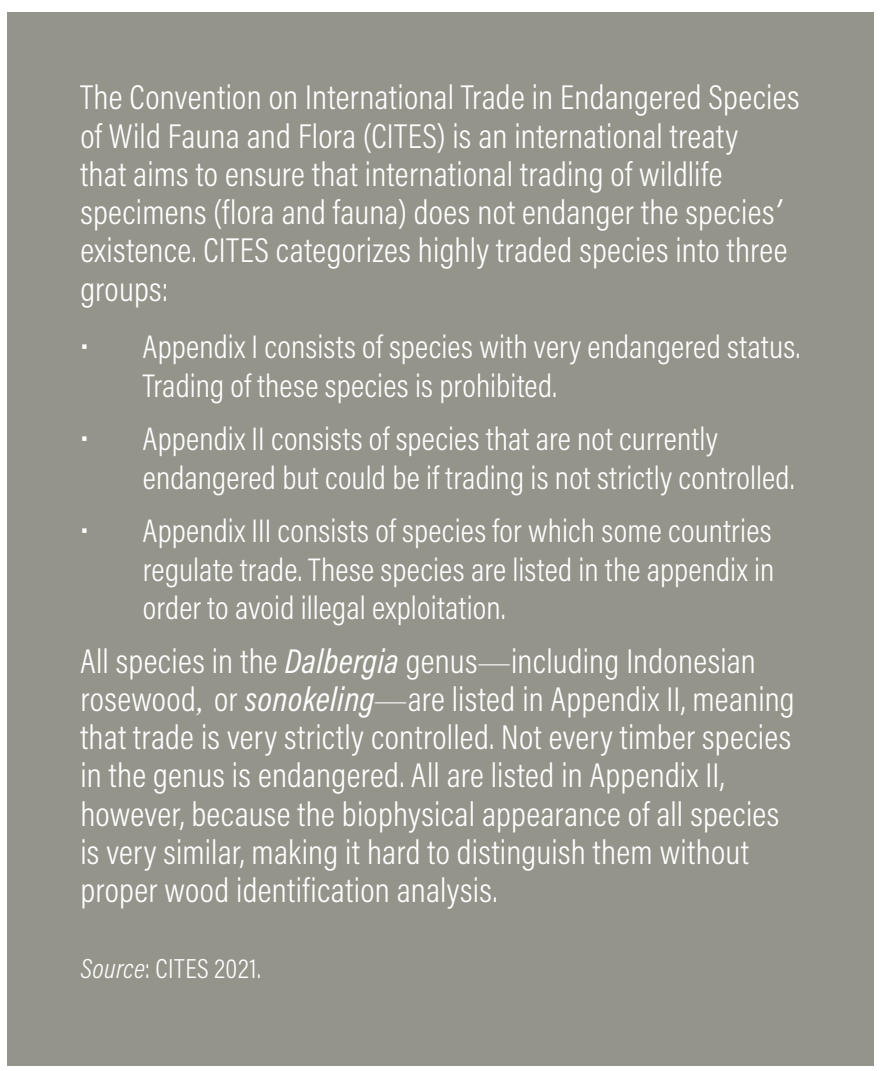

Table 3 | Documentation Required for Transporting and Exporting Teak and Rosewood

\begin{tabular}{|c|c|c|}
\hline STAGES IN SUPPLY CHAIN & $\begin{array}{l}\text { REQUIRED TRACEABILITY DOCUMENTS } \\
\text { Teak (Tectona grandis) }\end{array}$ & $\begin{array}{l}\text { TIMBER PLANTATIONS IN STATE FORESTS } \\
\text { (IUPHHK-HTI AND SOCIAL FORESTRY SCHEME) } \\
\text { Rosewood/sonokeling (Dalbergia latifolia) }\end{array}$ \\
\hline Domestic trade & $\begin{array}{l}\text { Transport Document (Nota Angkutan) to } \\
\text { accompany logs from forest to the next } \\
\text { destination (log pond/sawmill); and Continued } \\
\text { Transport Document (Nota Angkutan Lanjutan) } \\
\text { to accompany logs or half-processed wood } \\
\text { from log pond/sawmill to the next destination }\end{array}$ & $\begin{array}{l}\text { Transport Document to accompany logs } \\
\text { from forest to the next destination (log pond/ } \\
\text { sawmill); and Continued Transport Document to } \\
\text { accompany logs or half-processed wood from } \\
\text { log pond/sawmill to the next destination } \\
\text { Domestic Transport of Plants and Animals } \\
\text { Letter (Surat Angkut Tanaman dan Satwa } \\
\text { Dalam Negeri) as additional domestic transport } \\
\text { document }\end{array}$ \\
\hline Export trade & $\begin{array}{l}\text { - V-legal document, which is an export document } \\
\text { required by the Timber Legality Assurance } \\
\text { System (Sistem Verifikasi Legalitas Kayu) }\end{array}$ & $\begin{array}{l}\text { - V-legal document } \\
\text { Overseas Transport of Plants and Animals } \\
\text { Letter (Surat Angkut Tanaman dan Satwa Luar } \\
\text { Negeri) as Convention on International Trade in } \\
\text { Endangered Species of Wild Fauna and Flora } \\
\text { export permit document }\end{array}$ \\
\hline
\end{tabular}

Notes: Information was compiled from Ministerial Decree No. 447 of 2003 on Administration of Extracting or Hunting and Distribution of Plants and Wildlife; Ministry of Environment and Forestry Regulation No. P.48/MENLHK/SETJEN/KUM.1/8/2017 and No. P.85/MENLHK/SETJEN/KUM.1/11/2016 on Private Forest; and interviews with subnational forestry officers during field visits. Source: WRI authors. 
Once timber or timber products reach an export company and are aimed for the export trade, the company should obtain the V-legal document from the certification body. Only certified companies can obtain the V-legal document for export clearance. Company certification is obtained after a long process of assessing compliance with SVLK regulations and regular surveillance done by the certification body.

To export rosewood, businesses must obtain a SATS-LN, which serves as a CITES permit for international trade compliance. In addition to the SATS-LN, when transporting CITES-listed timber products domestically, all industries need to obtain a SATS-DN as proof of the legality of the sold timber. It is noteworthy that the Transport Document and Continued Transport Document are self-issued documents whereas the V-legal document, SATS-LN, and SATS-DN are officially issued documents.

The SATS-LN is issued by MoEF's Directorate General of Natural Resources and Ecosystem Conservation (Direktorat Jenderal Konservasi Sumber Daya Alam dan Ekosistem; Dirjen KSDAE) in Jakarta. Dirjen KSDAE will issue a SATS-LN if a timber company can provide the V-legal document and the SATS-DNissued by the Office of Natural Resources Conservation
(Balai Konservasi Sumber Daya Alam; BKSDA) — at the subnational level. An additional levy, the Levy on Overseas Trade of Plants and Wildlife (Pungutan Perdagangan Tumbuhan/Satwa Liar Ke Luar Negeri), is imposed to obtain the CITES permit. This levy amounts to 5 percent of total exported timber volume, with each cubic meter charged Rp1.5 million. A company that exported $1,000 \mathrm{~m}^{3}$ of Indonesian rosewood products per shipment would thus face a levy of Rp75 million (about US\$5,300). Due to the complication and this additional cost for exporting rosewood, several exporting companies we interviewed admitted that there are dishonest companies intentionally misdeclaring wood species as species not listed in CITES. This practice is possible because the final timber products made from different wood species are often similar and thus indistinguishable, and random checks of export products are not done meticulously.

Timber sourced from nonstate forests in Yogyakarta and Klaten can come from various actors and involves different stages of the timber trade, from farmers to processing industries or exporting companies. Most of the final products are assembled furniture. Largescale industry sometimes integrates several stages of the supply chain under one company, which owns the sawmill, makes the furniture, and sells the products

Figure 1. | Summary of Noncompliance with Timber Traceability Requirements

\begin{tabular}{|c|c|}
\hline \multirow[b]{2}{*}{ Farmer } & Noncompliance includes the following: \\
\hline & All timber species: No copy of land certificate and no issuance of Transport Document (Nota Angkutan) as proof of legality \\
\hline \multirow[b]{2}{*}{$\checkmark$} & Addition for rosewood: No SATS-DN document as Transport Document \\
\hline & Noncompliance includes the following: \\
\hline $\begin{array}{l}\text { Timber } \\
\text { Trader }\end{array}$ & $\begin{array}{l}\text { All timber species: Use single Transport Document (Nota Angkutan) for all timbers } \\
\text { bought from different farmers of sources }\end{array}$ \\
\hline \multirow[b]{2}{*}{$\nabla$} & - Addition for rosewood: Use SATS-DN obtained by trade with bigger trade capacity as Transport Document \\
\hline & Noncompliance includes the following: \\
\hline Sawmill & $\begin{array}{l}\text { Receiving timber from unclear source outside Yogyakarta/Klaten or other areas with high risk of illegal logging activities } \\
\text { Selling timber to the next link in the chain with a Continued Transport Document (Nota Angkutan Lanjutan) containing } \\
\text { false information that legitimates the timber source }\end{array}$ \\
\hline 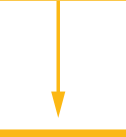 & Noncompliance includes the following: \\
\hline \multirow[t]{2}{*}{$\begin{array}{l}\text { Processing } \\
\text { Industry/ } \\
\text { Exporting } \\
\text { Company }\end{array}$} & $\begin{array}{l}\text { All timber species: Failure to verify timber information contained in Continued Transport Document (Nota Angkutan } \\
\text { Lanjutan) when receiving timber from sawmills or primary industries: failure to obtain V-legal document and instead } \\
\text { enable company to illegally export timber products under the name of a certified company }\end{array}$ \\
\hline & $\begin{array}{l}\text { Addition for rosewood: Misdeclare timber species with non-CITES species to avoid additional levy charge and } \\
\text { complication in obtaining SATS-LN document as export clearance }\end{array}$ \\
\hline
\end{tabular}

Notes: CITES = Convention on International Trade in Endangered Species of Wild Fauna and Flora; SATS-DN = Surat Angkut Tanaman dan Satwa Dalam Negeri (Domestic Transport of Plants and Animals Letter); SATS-LN = Surat Angkut Tanaman dan Satwa Luar Negeri (Overseas Transport of Plants and Animals Letter). 
overseas. Our observations showed that most of the actors failed to satisfy SVLK requirements for traded timber (Table 3) due to administrative complications, which resulted in a higher cost burden. Figure 1 summarizes the noncompliance found from field observations, and Figure 2 outlines the different legal documents required during each stage of the timber supply chain for rosewood.

Based on our observations, we concluded that the instances of noncompliance, such as illegal timber being mixed up with legally sourced timber and the misdeclaration of timber species, are possibly leading to timber laundering. This practice leads to illicit trading in domestic and international markets. In the upstream chain, dominated by farmers, noncompliance may be due to mitigating circumstances. Some farmers we interviewed said that although they cannot show land certificates, they legitimately hold the land tenure because their family members have owned the land for generations and land tenure was not well documented in the past. Timber traders, who buy timber from several sources and farmers, tend to avoid complications by issuing a single Transport Document for all the timber. A government official whom we interviewed affirmed that the Transport Document is often nontraceable to its source during random document checks.

Small and medium businesses along the downstream chain, whose total trade value is less than Rp10o million (approximately \$7,000) annually, admitted that the complications and high cost of pursuing V-legal certification are burdensome for them. They also reasoned that downstream businesses should not bear the responsibility of checking the legality of timber bought with a legal Transport Document; instead, they felt it should be the responsibility of the previous links in the chain to ensure timber legality. In rosewood domestic trade, these businesses rarely pursue a SATS-DN. They use the SATS-DN of another company by transporting their product under that company's name. This practice is certainly violating the prevailing regulation. This practice has also neglected the role of BKSDA officials in monitoring CITES-listed timber volume transported outside and inside the province. They only abide by the regulation if the trade destination is located in a province where the officials strictly monitor the import and export of CITES-listed timber and apply stringent law enforcement of the illegal trade, such as in East Java Province.

Figure 2. | Legal Documentation Required During Each Stage of the Rosewood Timber Supply Chain
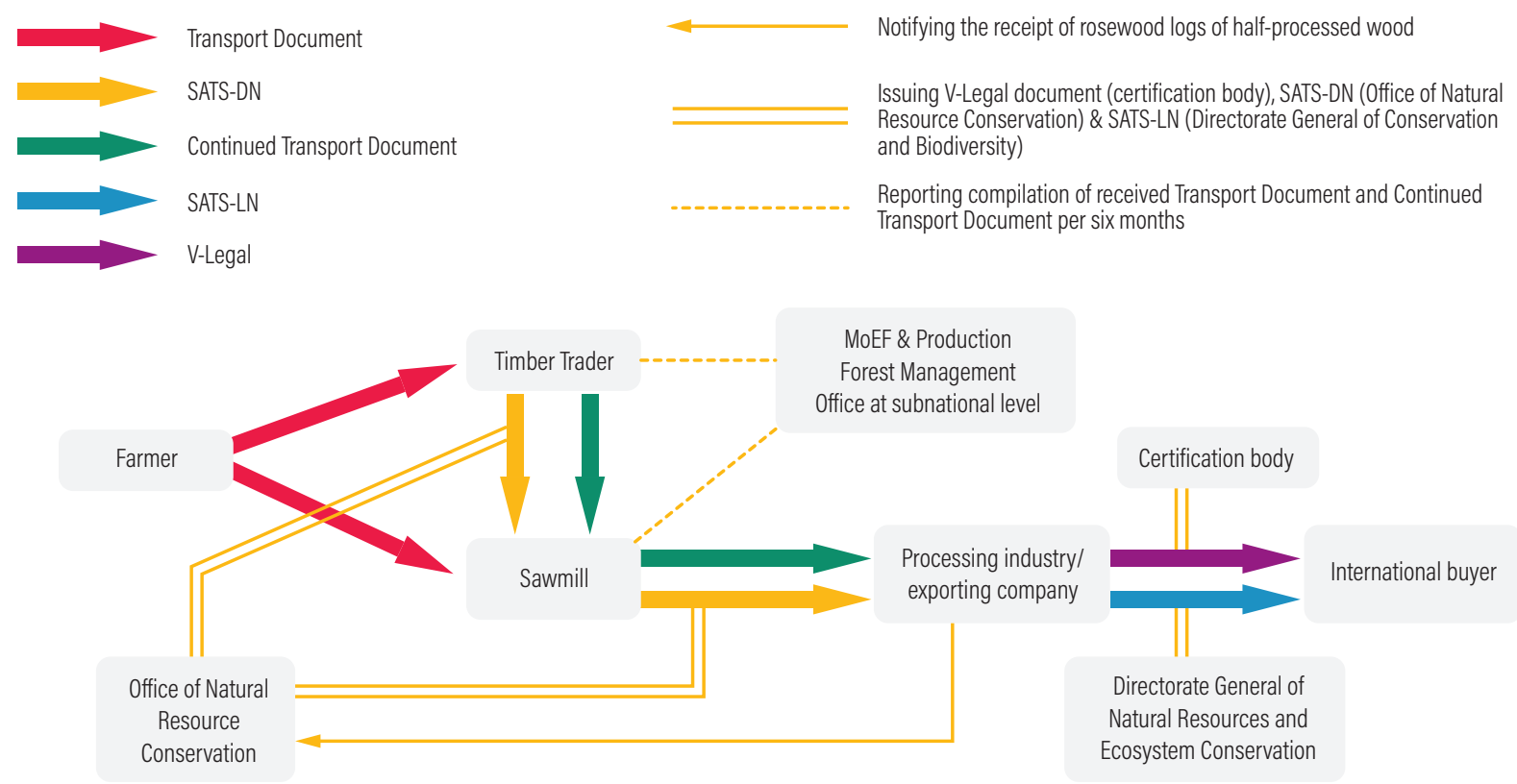

Notes: MoEF = Ministry of Environment and Forestry; SATS-DN = Surat Angkut Tanaman dan Satwa Dalam Negeri (Domestic Transport of Plants and Animals Letter); SATS-LN = Surat Angkut Tanaman dan Satwa Luar Negeri (Overseas Transport of Plants and Animals Letter).

Source: WRI authors. 
Substantively, the risk of illegal logging in Yogyakarta Province is relatively low due to some conditions.

First, most of the farmers whom we interviewed were holding land tenure rights, but they did not pursue the legitimate land certificate document. Second, the state forest area is much smaller in size than the nonstate forest area-approximately 18,715 hectares and 75,120 hectares, respectively (Yuwono and Listyanto 2017) and there is no Perhutani area or forest concession. These conditions present a low risk of timber smuggling from state forests and Perhutani. On Java Island, most illegal logging activities stem from different perceptions of the property border between Perhutani and the local community (Apriando 2013). However, some downstream industry officials interviewed admitted that they had received timber from outside Yogyakarta and Java Island. The flow of timber across regions without proper records increases the potential risk that illicit timber from other regions - such as Sumatra, Nusa Tenggara, and Kalimantan, where illegal logging activities are high-will reach Java Island. This finding was confirmed by the certification bodies we interviewed, which found the same thing during their surveillance and audit in areas outside of Java island.

Timber traceability issues are becoming more critical at upstream industries due to improper documentation at the timber source. Sawmills and processing industries receiving harvested timber from nonstate forests rarely verify the sources if a Transport Document is attached to the logs. The timber price concern always trumps the legality issues unless their main consumers explicitly require timber source verification to comply with certain certification standards. Some industries prefer not to be SVLK certified, however, and they use another company's name to acquire the V-legal document to fulfill their export clearance documentation. This fraudulent method is not uncommon, but the certification body admitted that it is hard to detect because the issuance of the $\mathrm{V}$-legal document relies heavily on the document completion checklist, and verifying the information for each document is seen as impractical and time-consuming for every V-legal document issuance request. From our interviews, we knew that, in some cases, buyers in importing countries intentionally asked producers in Indonesia to change the timber species to a less-restricted species when shipping the timber products-for example, changing rosewood to teak-to avoid strict customs clearance and checks in the destination country. This practice is seen as mutually beneficial for both producer and consumer companies. The producer company will not pay timber levies for exporting CITES-listed timber, and the practice avoids complications in clearing customs and checks borne by the consumer company.

Our findings from the case study in Klaten and Yogyakarta show that there was a potential risk of illegal timber trading caused by irregularities and noncompliance with SVLK implementation, especially at downstream industries, where misdeclaration of timber species and origin in timber documentation can put the credibility of the SVLK at risk. The system, which operates with minimum supervision and relies on fulfilling the document checklist, enables dishonest actors to perform timber laundering. The lack of efforts to monitor the movement of protected timber from one area to other and in domestic trade can weaken the effort to improve timber traceability and can increase the risk of forest encroachment and illegal logging leakage to other areas. Attention should be given to areas with vast forest cover, such as Papua, Kalimantan, Sumatra, and Sulawesi. Reports show that illegal logging still massively occurs in these areas, and illegal timber has been transported to Java by falsifying timber species and origins in the Transport Document.

Past studies (Dormontt et al. 2015; Hartvig et al. 2015; Hassold et al. 2016) have shown promising results for the use of wood ID technologies to recognize species and trace timber back to its origin. By understanding that timber species and origins are the most commonly falsified information in timber documentation, these technologies can be applied in the SVLK to help prevent document falsification that leads to illegal timber trading. The application of these technologies has been used in two important cases in the United States. The first case provided evidence that Lumber Liquidators, a U.S. retailer of hardwood flooring, deliberately imported timber harvested from the Russian Far East and declared it as having originated in Germany. The Environmental Investigation Agency applied stable isotope analysis to identify the origin of samples obtained from Lumber Liquidators' Chinese supplier (EIA 2013). In the second case, a team consisting of Double Helix Tracking Technologies and the University of Adelaide, with the help of the World Resources Institute, assisted the U.S. Forest Service in proving the illegal cutting of big-leaf maple trees (Double Helix Tracking Technologies 2018). The team applied deoxyribonucleic acid (DNA) fingerprinting by comparing the DNA/genotype profile of seized sawed 
wood with the alleged stumps in the Gifford Pinchot National Park. It took about 400 samples from the DNA reference database to find the actual stump, which was located in an area where cutting was banned. However, applying these technologies requires a huge investment in infrastructure and human resources during the early stage of development.

The next sections of this paper will give a brief overview of some wood ID technologies and discuss Indonesia's level of capacity-in terms of the availability of laboratory equipment to run the analysis, the technical expertise to apply the technologies, and the wood sample database used as a reference- - to support the application of wood ID technologies in timber traceability.

\section{AN OVERVIEW OF WOOD ID TECHNOLOGIES}

In the timber trade, identifying wood species is critical for ensuring that endangered species are not overharvested and traded. Techniques used in wood ID technologies to identify species are divided into visual observation and analysis of the chemical substance and DNA of the wood. This section briefly elaborates on the different types of wood ID technologies to explain which type is applicable in different document falsification situations.

\section{Wood Anatomy}

Timber ID based on the composition of wood cell structures (both macroscopic and microscopic) have been used for many years (Carlquist 2001). Simple techniques were often used, such as making cuts with a knife and observing with a magnifying glass. Much thinner slices can be procured for observation under a microscope.

The anatomical properties of wood are strongly affected by its taxa (family, genus, species) and, to some extent, the environment where the tree grows. For example, specific characteristics such as the presence of resin ducts or ring-width variations can allow the wood's origin to be identified (Sonsin et al. 2012; Wimmer et al. 1997) (Figure 3). In some cases, wood anatomy can be used to differentiate timber up to the species level; in others, it can be used only up to the genus level.

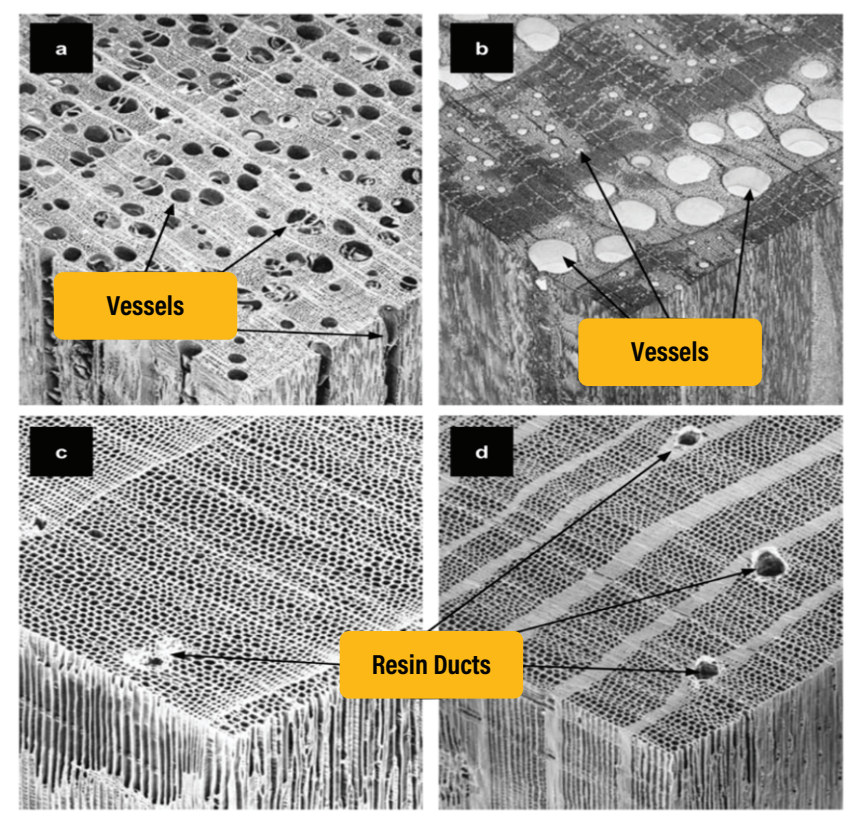

Notes: The figure shows black walnut (panel a), red oak (panel b), eastern white pine (panel c), and southern yellow pine (panel d). Panels a and b are hardwoods and therefore possess vessels. Panels $\mathrm{c}$ and $\mathrm{d}$ are softwoods and do not possess vessels.

Source: Hoadley 2000. 


\section{Machine Vision}

Machine vision applies machine learning, a term for the algorithms and statistical models that computers use to perform tasks by relying on patterns. Sample data (often called training data) are fed into the algorithm so that it can develop a mathematical model for making decisions. Figure 4 shows how machine learning can be used to identify wood species.

A machine vision system consists of a sensor, a reliable algorithm for pattern recognition, and a good database as a reference. The three components are mandatory for the system duplication. Once system duplication is fulfilled, it can be widely used by field officers for wood ID and to reduce the money spent to train field officers to be experts on wood anatomy.

Conceptually, machine vision systems for identifying wood are analogous to traditional wood anatomy ID based on visual inspection. In both cases, a sensor (an eye, camera, or other detector in a machine) receives a signal, and a processor (the brain or central processing unit) analyzes it. ID can then be made based on crosschecking the extracted features with a wood anatomy database such as InsideWood (Wheeler 2011) or by conducting a classification process using a mathematical model.

Machine vision is preferred over wood anatomy because of its potential for decentralized use. Some examples of portable machine vision technology are the XyloTron, developed by the U.S. Department of Agriculture Forest Product Laboratory, and the Automatic Wood Identification Tool (Alat Identifikasi Kayu Otomatis; AIKO), developed jointly by MoEF and LIPI (Damayanti 2018).

\section{Near-Infrared Spectroscopy}

Near-infrared spectroscopy (NIRS) measures the absorption spectra of material when exposed to nearinfrared electromagnetic energy. For organic materials, it works with electromagnetic waves within the 780-2,500 nanometer wavelength. Diffuse reflectance or absorption spectrum data can clearly distinguish different types of materials (Tsuchikawa et al. 2003). The technology requires a robust statistical model, such as the Mahalanobis distance and partial least squares regression, to do so reliably, however (Pastore et al. 2011; Tsuchikawa et al. 2003).

NIRS technology can distinguish different genera, different species of the same genus, and the same species in different regions (Figure 5). It can also identify the wood's place of origin (Yang et al. 2015). Although it is not as precise as DNA technology (described below) or the anatomy technique, it is faster than both. NIRS technology works by measuring different chemical components of timber (Karlinasari et al. 2014). Compared to other technologies, NIRS is relatively underdeveloped, even at the global level.

\section{Direct Analysis in Real Time (Time of Flight) Mass Spectrometry}

Direct analysis in real time (time of flight) mass spectrometry (DART-TOFMS) allows rapid analysis of the full chemical profile of any sample with little or no sample preparation. The sample analyzed is exposed to a stream of helium ions heated to $450^{\circ} \mathrm{C}$. The high temperature of this ion stream vaporizes the chemicals on or near the surface of the sample. The mass spectrometer measures the chemical composition

Figure 4. | Simple Flowchart of a Machine Learning System

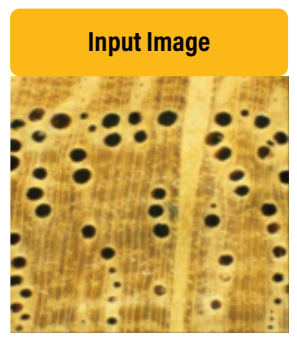

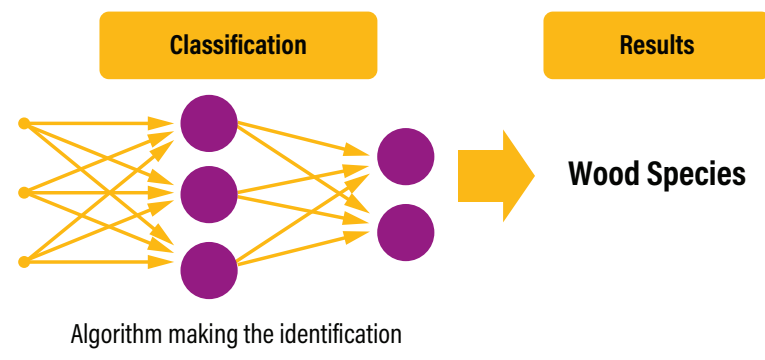

Vessel size, vessel groupings, etc

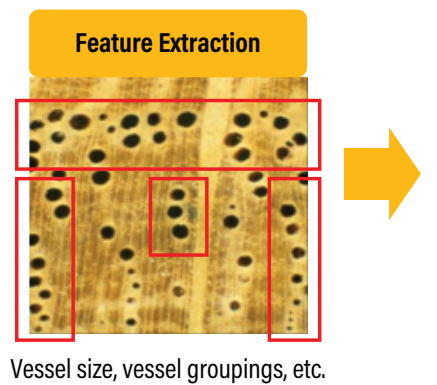


Figure 5. | The Near-Infrared Spectra of Three Wood Species in Three Sections

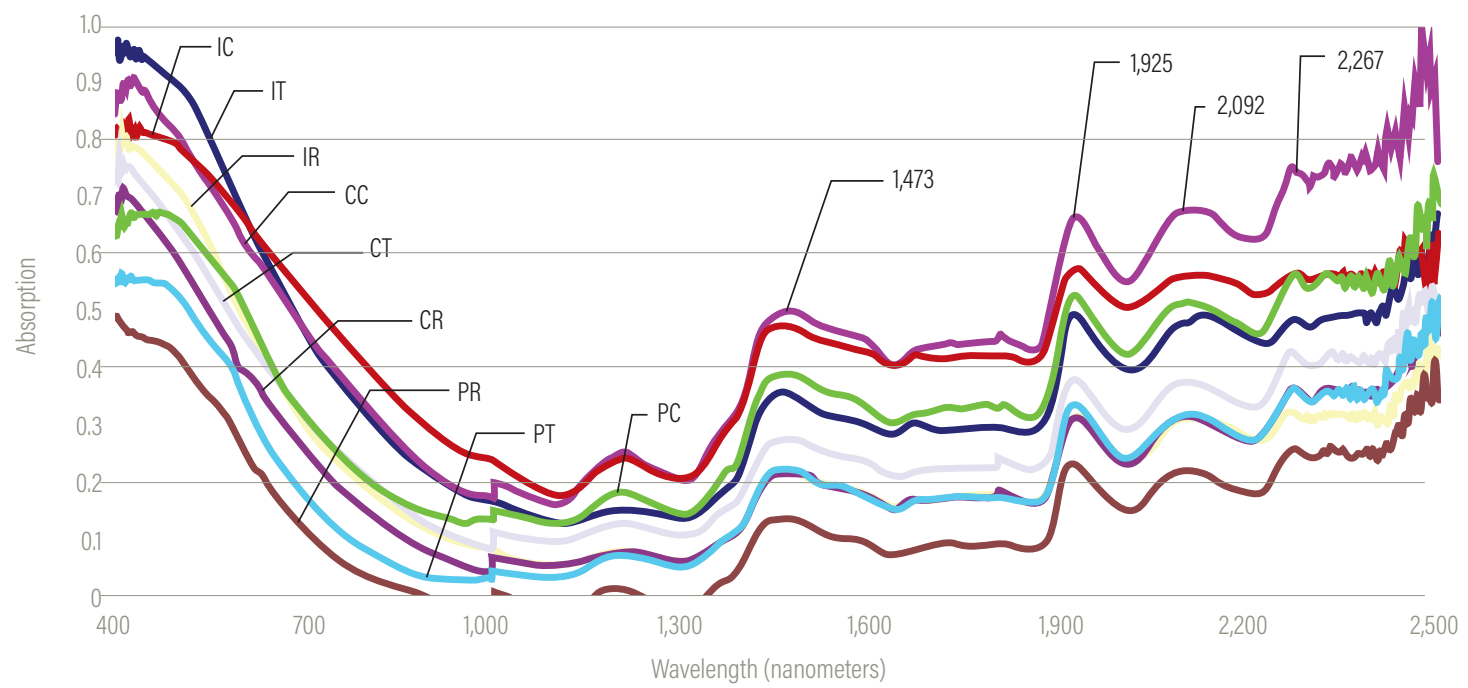

Notes: The first letter corresponds to the wood species $(\mathrm{I}=$ Intsia, $\mathrm{C}=$ Couratari, $\mathrm{P}=$ Pometia $)$, and the second letter stands for the corresponding sections $(\mathrm{C}=$ cross section, $\mathrm{R}=$ radial section, $T$ = tangential section) of samples.

Source: Yang et al. 2015.

of the sample in the form of a mass spectrum. From this mass spectrum, chemicals can be inferred by comparing the measured mass with chemical databases (Figure 6). Similarly, species are identified by comparing mass profiles to databases of wood species mass spectra.

DART-TOFMS can differentiate species under the same family and genus, such as the Araucariceae family (Evans et al. 2017) and Dalbergia genus (Espinoza et al. 2015; Lancaster and Espinoza 2012), two of which are listed in CITES. The Araucariceae family of tree species is distributed in various geographical extents, and DART-TOFMS can differentiate some of the species. This technology has proved to be able to determine the origin of different Pseudotsuga menziesii timbers within a small geographical extent (Finch et al. 2017), and it can distinguish whether Aquilaria timber is from a plantation or grew naturally (Espinoza et al. 2015).

Figure 6. I Sampled Regions and the Corresponding DART-TOFMS Spectra
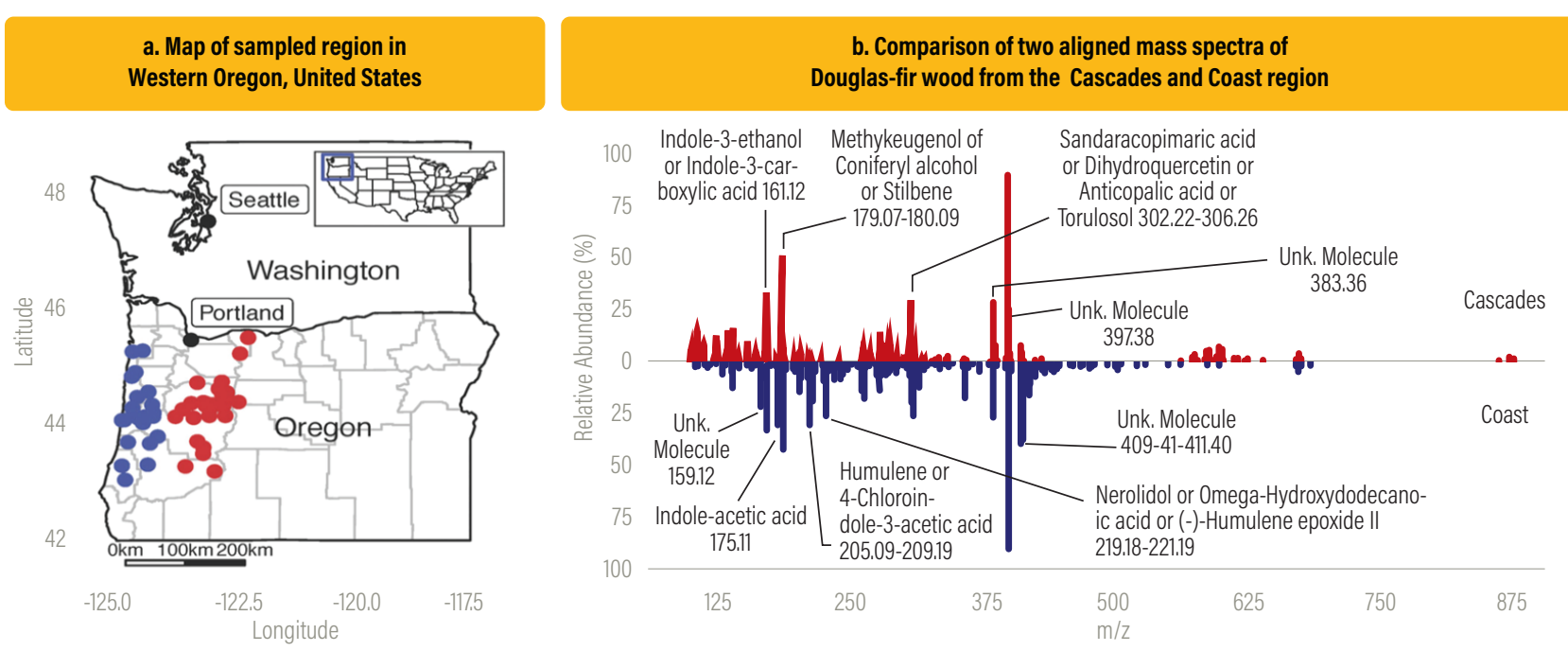

Notes: In panel a, points in red are in the Cascades region; points in blue are in the coast region.

Source: Finch et al. 2017. 


\section{Stable Isotope Analysis}

In technical terms, isotopes are atoms that have the same number of protons and electrons but a different number of neutrons. Isotopes exist in every naturally occurring element, and whereas some are radioactive, others are stable. Stable isotope ratios are measured using mass spectrometry. Measuring isotope ratios of carbon and four other chemical elements (nitrogen, sulfur, hydrogen, and oxygen) have shown good results in tracing timber origin. Lee et al. (2015) have successfully differentiated Korean red pine timber growing inland from red pines growing in coastal areas through the different isotopic composition of hydrogen $\left(\delta^{2} \mathrm{H}\right)$ and oxygen $\left(\delta^{18} \mathrm{O}\right)$ found in the timber's organic tissue. This result can be used as the basis to identify timber origin. However, this technology is limited in its ability to determine information pertaining to timber genus or species.

Stable isotope analysis to identify timber origin compares the timber sample signature with the stable isotope reference analysis data set of samples collected in the region of interest. Analysis of isotopes combinations of carbon, oxygen, hydrogen, nitrogen, and sulfur found in timber organic tissue has proved to be effective in differentiating the teak timber (Tectonia grandis) species grown in different regions (Förstel et al. 2011).

\section{DNA Analysis}

The genetic material of each species is unique and tree population characteristics are site specific, resulting from exposure to different conditions over time; hence, the genetic information contained in a tree species can show spatial information. DNA analysis of timber can provide accurate information about species and origin. In chain-of-custody verification, DNA analysis works as a barcode for species validation, a spatial ID of tree population, and a timber fingerprint (i.e., genotyping and tracking; Galpern et al. 2012). Table 4 shows different DNA analysis technologies for identifying timber.

As part of forensic tools, DNA analysis can accurately determine timber species and origin, and it is convincing evidence in law enforcement. In recent years, many genetic approaches have been used to verify the origin and trade routes of protected wildlife species, including elephant ivory (Wasser et al. 2004), sturgeon and paddlefish caviar (Ogden et al. 2013), tigers (Kitpipit et al. 2012), birds (Abe et al. 2012), and fishes (Clemento et al. 2014). Several marker sets have been developed and tested in plants, namely Gonystylus (Ogden et al. 2008), Intsia (Lowe et al. 2017), Swietenia (Degen et al. 2013), Larix (Blanc-Jolivet et al. 2018), and Cedrela (Finch et al. 2020; Paredes-Villanueva et al. 2020). Lowe and Cross (2011) reported that DNA technology can be broadly applied to trace the origin of timber (Figure 7), and analysis methods continue to become available and improved (Degen et al. 2013). However, DNA analysis has certain limitations for detecting processed-wood products because DNA extraction from these products is much more difficult than extracting DNA samples from trees and/or logs.

The various methods and techniques applied in wood ID technologies suggest that each technology has strengths and weaknesses in different situations and for different purposes. Whereas some technologies are more practical for field checkpoint screening or random export checks, others are more precise for illegal logging investigation purposes. Dormontt et al. (2015) summarized the distinct abilities of each wood ID technology (Table 5). It should be noted that these results are not exhaustive; there are many nuances

Table 4 | DNA Technology Methods to Identify Wood

\begin{tabular}{|c|c|c|}
\hline TECHNOLOGY & CONCEPT & USE IN TIMBER TRACEABILITY \\
\hline $\begin{array}{l}\text { Deoxyribonucleic acid (DNA) } \\
\text { barcoding }\end{array}$ & $\begin{array}{l}\text { Small portion of DNA (unique to each species) is } \\
\text { identified }\end{array}$ & $\begin{array}{l}\text { - To verify wood species declared in } \\
\text { administration document }\end{array}$ \\
\hline Population genetics & $\begin{array}{l}\text { Genetic differences based on natural selection, } \\
\text { genetic drift, mutation, or gene flow are examined }\end{array}$ & $\begin{array}{l}\text { - To identify place of origin } \\
\text { - To determine whether the timber comes from a } \\
\text { plantation or grows naturally }\end{array}$ \\
\hline DNA fingerprinting & $\begin{array}{l}\text { DNA is used to identify an individual within a } \\
\text { species }\end{array}$ & $\begin{array}{l}\text { - To verify the chain of custody of the timber } \\
\text { - To prove timber laundering }\end{array}$ \\
\hline
\end{tabular}




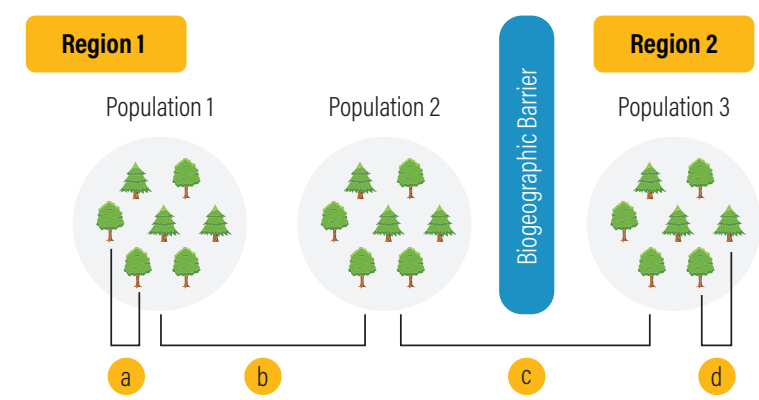

Source: Cao et al. 2009; Lee et al. 2016; Lowe and Cross 2011; Ritonga et al. 2018.

within each method, and some scientists might have different results from their own experiments, which rebut previous scientific conclusions.

Interviews with Indonesian wood experts indicate that the wood anatomy technique is the most widely used method to identify timber. The Xylarium Bogoriense has been contacted regularly to identify timber species for commercial and investigation purposes. Our interview with a wood anatomy scientist, who was also an expert witness in illegal logging cases, implies that a census of 300 stumps was needed to verify that eight stolen logs came from the claimed reference stumps. Photos of the logs and stumps were collected and used to check whether the bottom part of the allegedly stolen logs matched the 300 stumps by observing their diameter and tree ring pattern. Stumps with physical characteristics similar to those of the stolen logs were short-listed for further analysis, which investigated their basic physical, mechanical, and chemical properties. According to the expert, though wood anatomy could match logs with particular stumps with abundant metadata, this methodology is very time-consuming and less accurate in verifying the origin.

Advanced timber tracking technology, such as stable isotope and DNA analysis, could help distinguish timber origin. Stable isotope and DNA analysis were able to distinguish merbau that originated in Papua, Indonesia, from merbau that originated in Papua New Guinea. ${ }^{2}$ This distinction could help reduce illegal timber movement and trading across countries and strengthen law enforcement within the region. The interviews with wood experts suggest that stable isotope and DNA

\section{Table 5 | The Level of Timber ID Based on Selected Methods Used in Forensic Analysis in Indonesia}

\begin{tabular}{|l|l|l|l|l|}
\hline \multicolumn{4}{l}{ LeVEL OF IDENTIFICATION } \\
Method & Genus & Species & Individual & Provenance \\
\hline Wood anatomy & Yes & Occasionally & No & Occasionally, but needs abundant metadata \\
\hline Machine vision & Yes & Occasionally & No & Unknown \\
\hline Mass spectrometry & Yes & Yes & No & Yes \\
\hline Near-infrared spectroscopy (NIRS) & Yes & Yes & No & Yes \\
\hline Stable isotope analysis & No & No & No & Yes \\
\hline DNA barcoding & Yes & Yes & No & Occasionally \\
\hline Population genetics & No & Occasionally & No & Yes \\
\hline DNA fingerprinting & No & No & No & No \\
\hline
\end{tabular}

Source: Cao et al. 2009; Lee et al. 2016; Lowe and Cross 2011; Ritonga et al. 2018. 
analysis had not yet been applied in illegal logging investigations in Indonesia, but some researchers outside of Indonesia have shown its potential to distinguish timber origin.

Lowe et. al (2017) applied DNA analysis to compare merbau timber sampled from a logging concession with merbau timber sampled from a sawmill. The findings showed that 27 out of 30 samples matched, suggesting that DNA analysis can trace wood origin. Research on DNA analysis of Shorea platyclados, Gonystylus bancanus, and Neobalanocarpus heimii (Tnah et al. 2010; Ng et al. 2016; Ng et al. 2017) in Malaysia has shown a promising result as a forensic tool in generating evidence, such as a match between stolen timber and the suspected tree source. The Selangor State Forest Department and the Forest Research Institute Malaysia have applied DNA analysis in an illegal logging case (Ng et al. 2016). Learning from this experience, Institut Pertanian Bogor (IPB) University and World Resources Institute are working on a Diospyros celebica reference database as a pilot project. A total of 322 samples were collected in 2019 from natural forests on Sulawesi Island, and analyses of these samples are now under way to extract wood ID materials for different technology applications, such as wood anatomy, NIRS, and stable isotope and DNA analysis.

In Indonesia, when investigating or confiscating allegedly illegal logs, the first step is to find out whether the logs were harvested from a state forest or a nonstate forest. Simple observation of the logs' diameters could help identify which logs came from natural or nonstate forests because the diameter of timber logs harvested from natural forests is generally larger than the diameter of logs harvested from plantations or nonstate forests. These technologies certainly provide more accuracy than human observation to determine the source of timber.

\section{THE TECHNICAL CAPACITY OF WOOD ID TECHNOLOGIES IN INDONESIA}

As mentioned in the previous section, applying wood ID technologies to the chain of custody requires laboratories with adequate equipment and tools. In addition, it also requires wood ID experts and technical staff to run the analysis, infrastructure to store the database and references, and timber materials extracted from samples to serve as references.

In Indonesia, some labs (Table 6) administered by universities, research institutions, and government agencies have been able to use techniques similar to wood ID technologies, but they rarely run for illegal logging investigations or law enforcement purposes. To enable wood ID technologies to fully operate in those labs, an important aspect should be made available: a reference data set of wood material for each technology, which would require a huge investment to develop.

Table 6 | Institutions with the Capacity to Run Wood ID Techniques and Analyses

\begin{tabular}{|c|c|c|}
\hline ORGANIZATION & SERVICE PROVIDED & ADDRESS \\
\hline Xylarium Bogoriense & $\begin{array}{l}\text { Genus identification, based on wood anatomy } \\
\text { analysis }\end{array}$ & $\begin{array}{l}\text { Jl. Gunung Batu No. 5, Bogor } 16610 \\
\text { email: info@pustekolah.org }\end{array}$ \\
\hline $\begin{array}{l}\text { Institut Pertanian Bogor (IPB) University, } \\
\text { Department of Forest Products }\end{array}$ & $\begin{array}{l}\text { Genus identification and wood chemical } \\
\text { compound analysis, based on wood anatomy } \\
\text { analysis }\end{array}$ & $\begin{array}{l}\text { Kampus IPB, Dramaga, Bogor } 16680 \\
\text { email: dhht@ipb.ac.id }\end{array}$ \\
\hline $\begin{array}{l}\text { Center for Forest Biotechnology and Tree } \\
\text { Improvement (Balai Besar Penelitian dan } \\
\text { Pengembangan Bioteknologi dan Pemu- } \\
\text { liaan Tanaman Hutan; BIOTIFOR) }\end{array}$ & $\begin{array}{l}\text { Deoxyribonucleic acid (DNA) analyses (random } \\
\text { amplification of polymorphic DNA, sequence } \\
\text { characterized amplified region, microsatellite, } \\
\text { and polymerase chain reaction) }\end{array}$ & $\begin{array}{l}\text { J. Palagan Tentara Pelajar Km. 15, } \\
\text { Purwobinangun, Pakem, Sleman, } \\
\text { Yogyakarta 55582 } \\
\text { email: breeding@biotifor.or.id }\end{array}$ \\
\hline $\begin{array}{l}\text { Biotechnology Research Indonesian-The } \\
\text { Netherlands Laboratory, IPB University, } \\
\text { Department of Silviculture }\end{array}$ & Wood genetic/DNA analysis & $\begin{array}{l}\text { Kampus IPB, Darmaga, Bogor } 16680 \\
\text { email: deptsilvik@ipb.ac.id } \\
\text { deptsilvik@apps.ipb.ac.id }\end{array}$ \\
\hline $\begin{array}{l}\text { Center for Isotope and Radiation Applica- } \\
\text { tion (Pusat Aplikasi Isotop dan Radiasi), } \\
\text { National Nuclear Energy Agency of Indo- } \\
\text { nesia (Badan Tenaga Nuklir Nasional) }\end{array}$ & Stable isotope analysis & $\begin{array}{l}\text { J. Lebak Bulus Raya №. 49, Jakarta Selatan } \\
\text { email : humas@batan.go.id }\end{array}$ \\
\hline
\end{tabular}


The Xylarium Bogoriense, established in 1915, claims to have 192,000 wood samples in its collection. With this enormous number of samples, the Xylarium Bogoriense has developed a wood recognition app to identify wood species. The app works the same way as the machine vision technology known as AIKO. It was designed to recognize 186 commercially traded wood species in Indonesia based on Ministerial Decree No. 163 of 2003 on Timber Species Categorization Based on Imposition of Forestry Levies. Some more species will be added to AIKO data sets in the near future. AIKO targets regional forest officers, forest businesspeople, and police officers from forensic units as users (Damayanti 2018). Starting in early 2020, the Xylarium Bogoriense began working with the U.S. Agency for International Development to automate wood ID with XyloTron, the portable identification tool that works the same way as machine vision.

The Center for Forest Biotechnology and Tree Improvement (Balai Besar Penelitian dan Pengembangan Bioteknologi dan Pemuliaan Tanaman Hutan; BIOTIFOR) specializes in DNA analyses (random amplification of polymorphic DNA, sequence characterized amplified region, microsatellite, and polymerase chain reaction). As a government institution, it focuses on forest biotechnology, plant breeding, and genetic modification to support plant breeding programs. Although wood ID technology is not a focus of BIOTIFOR, its laboratory is capable of conducting it. Additionally, this Institut Pertanian Bogor University lab is supported by adequate experts and equipment is also able to conduct DNA analysis.

The Center for Isotope and Radiation Application (Pusat Aplikasi Isotop dan Radiasi) of the National Nuclear Energy Agency of Indonesia (Badan Tenaga Nuklir Nasional) conducts stable isotope analysis. Its forest laboratory conducts fingerprint analysis of water, supported by a reasonably good hydrology database. The lab is equipped with isotope ratio mass spectrometry for wood ID analysis, but since a wood reference database has not yet been developed, wood ID analysis is not possible.

Interviews with officials from the institutions listed in Table 6 suggest that Indonesia has moderately decent wood ID capacities, in which wood anatomy ID still dominates. DNA analysis can produce highly accurate results about wood species, but it is less favorable because some of the stages of analysis cannot be conducted in Indonesia, such as DNA sequencing, which makes the process more time-consuming. Table 7 shows the state of various wood ID technologies and methods in Indonesia.

\section{Table 7 | The State of Wood ID Techniques Available in Indonesia}

\section{METHOD}

Wood anatomy

Machine vision

\section{CURRENT STATE}

Analysis is supported by the wood sample collection of the Xylarium Bogoriense, which is managed by the Forest and Environment Research, Development and Innovation Agency (FORDA) of the Ministry of Environment and Forestry.

FORDA has also developed a wood identification app called AlKO to analyze commercial wood species. This app is accessible to the public through smartphones, but users have to pay fees for each wood identification analysis.

Near-infrared spectroscopy (NIRS)

Indonesia has a plan to develop this technology through cooperation with Japan and Southeast Asian countries, but it is struggling to secure funding to do so. The Institut Pertanian Bogor (IPB) University is currently testing known-origin samples of Diospyros celebica to determine whether NIRS technology can discriminate between different locations within the same species.

Stable isotope analysis Equipment is available, but it has not been tested for wood. Application of this technology to wood is for research purposes only. The results of analysis have not yet been verified.

Direct analysis in real Equipment is not available, but with funding support, it could potentially be developed. time (time of flight)

mass spectrometry

Deoxyribonucleic acid (DNA) analysis
Several types of DNA-related techniques are used, including DNA extraction from wood, DNA barcoding, and population genetics. Its potential as a method to verify wood species and origin is still moderately known. World Resources Institute and IPB University are collecting samples of Diospyros celebica, an ebony tree endemic to Sulawesi Island, to develop a wood reference database, including DNA reference. The limitation of conducting DNA sequencing in the country has caused some samples to be analyzed abroad. 
With current capacities predominantly relying on wood anatomy, Indonesian research institutions could help to verify timber species. Timber origin information could be determined by researching where the species grow; however, this information has limited accuracy compared to other more advanced forensic techniques such as DNA analysis. Indonesia already has adequate human resource capacity to apply other technologies with better accuracy of timber origin data generation, such as stable isotope and DNA analysis. However, developing a wood reference database is necessary, and wood samples of standing trees should begin to be collected across the country.

To combat illegal logging and illicit timber trading, the technical capacity of applying wood ID technologies should be complemented by a legal framework in which the use of wood ID technologies is accredited as convincing proof of a criminal offense and as part of the timber chain of custody.

The success stories of applying wood ID technologies to prove misdeclarations of timber species and origin suggest the technologies can also tackle the issue of SVLK noncompliance found in Klaten and Yogyakarta. The abilities of these technologies to generate timber information (shown in Table 5) imply their potential applications for tackling different types of noncompliance. Therefore, integrating such technologies into the SVLK as part of the chain of custody and export clearance can prevent illegal timber trading and transport. In cases where timber species are misdeclared to avoid administrative complications and export trading levies-for example, claiming that a rosewood timber product is a teak timber product-the application of mass spectrometry and DNA barcoding can help detect this falsification. Illegal timber movements from forest-rich islands such as Sumatra, Kalimantan, Sulawesi, and Papua to Java Island can be detected by applying population genetics and stable isotope analysis, which are able to identify timber species and provenance. Undercover investigations conducted by independent monitors and periodical surveillance by certification bodies will require a more practical technique to detect information falsification in timber documentation. Portable tools such as AIKO and the XyloTron can be useful to detect misdeclared timber species in transport and administration documents.

Different from noncompliance of SVLK implementation, in law enforcement, more advanced technology with higher accuracy is required for illegal logging litigation in court. For instance, in one court case, five companies were accused of using fake documents and barcodes to transport 81 containers of wood logs from Nabire, Papua
Province, to Surabaya (Asrida 2018). The application of DNA fingerprinting could trace the wood logs back to their tree stumps and serve as strong evidence in court if the logs were harvested outside the concession area.

\section{CONCLUDING REMARKS}

Preserving forests is a priority for a tropical country such as Indonesia, especially given the high rate of deforestation. The establishment of the SVLK, which calls for mandatory certification, represented a milestone in tracking timber in Indonesia. Yet some loopholes remain, such as document falsification. To tackle the issue of illegal logging and stop deforestation, the SVLK needs to be equipped with science-based tools that can close these loopholes in the system.

Wood ID technologies have proved to be able to detect any misdeclaration of timber species and origin - the two most commonly falsified elements of timber documentation. Applying these technologies can improve the timber chain of custody, strengthen the SVLK as a legal assurance system, and stop illegal logging and illicit timber trading. To apply these technologies, certain conditions should be met, including decent infrastructure to support the analyses and an adequate number of experts to carry them out. Some Indonesian laboratories with advanced equipment and tools have shown the potential to carry out wood ID analyses, and Indonesia will need to accelerate the uptake of these technologies to enforce the law and strengthen efforts to halt deforestation.

Support should be given to institutions that have sufficiently equipped laboratories and adequate expertise to carry out wood ID techniques and analyses. Such institutions include BIOTIFOR and the Xylarium Bogoriense (wood ID technique) as well as the Center for Isotope and Radiation Application (stable isotope analysis). IPB University and World Resources Institute are collaborating to develop a reference data set for Diospyros celebica, an ebony tree endemic to Sulawesi Island, where the collection of wood samples has been completed this year. Database development for other commercial and widespread timber species will be an important initial step to enable the use of wood ID technologies.

There are a few practical considerations that should be addressed before implementing the technologies. First, understanding the distribution of different tree species on different islands or across regions can help with the preliminary analysis of timber, and tree inventories play an important role. When allegedly illegal timber is found and investigated, information about where 
the tree species grows can give an initial indication of whether timber origin information matches with tree species distribution. Some studies on timber species inventories have been conducted, but the results were not well documented or made publicly available. With subnational offices spread across the country, MoEF could possibly conduct tree inventories in the same way that some forest management unit offices recorded the standing stock and tree species in their working areas (conservation, protected, and production forest). By regulation, concession companies are obliged to submit a map of the standing trees in their concession area to MoEF, from which MoEF can collate the data and make them publicly available.

Second, the prioritization of species needs to be based on indicators of importance. Huge investment is needed to create a reference database of wood and leaf samples, which is no small task on an archipelago. Therefore, it needs to be developed gradually based on funding availability because references need to be gathered for each individual species and then incorporated into the database. For law enforcement purposes, some indicators of selection can be the frequency of being illegally logged, high commercial value (in terms of levies and trade duties), and restriction by national law. In addition, practical considerations should be included for feasibility in sample collection, such as species distribution (widespread or concentrated), accessibility, scarcity, and whether the species is grown on a plantation or grows naturally.

Table 8 gives an example of how teak and rosewood are assessed with the indicators mentioned above. Teak and rosewood are plantation trees, so they may not be worth sampling for reference development from a law enforcement perspective, but Table 8 can give a sense of how to do this with naturally grown trees.

Third, it is important to understand how officials and law enforcement can use these technologies in the field. Some technical issues may occur during an investigation and verification that can hinder the optimum utilization of these technologies. Forensic work requires fresh samples for analysis, which can affect the accuracy of the result (Ferri et al. 2009; Julian et al. 2018). The closer (spatially and temporally) a field investigation is to the origin of the timber, the more likely it is to correctly identify the wood from the fresh sample analyzed. Thus, setting up checkpoints close to the concession areas is ideal for improving enforcement (Hermanson and Wiedenhoeft 2011) and harnessing the wood ID tools.

Table 8 | Indicators for Prioritizing Which Species to Include in a Wood Reference Database

\begin{tabular}{|c|c|c|}
\hline INDICATORS & TEAK (TECTONA GRANDIS) & $\begin{array}{l}\text { INDONESIAN ROSEWOOD } \\
\text { (DALBERGIA LATIFOLIA) }\end{array}$ \\
\hline High value or commercially traded & $\begin{array}{l}\text { Grade A2 (a timber grade determined based on diameter } \\
\text { size classification [about } 20-29 \text { centimeters]) costs } \\
\text { about US } \$ 215 \text { per cubic meter }\end{array}$ & Grade $A 2$ costs about $\$ 570$ per cubic meter \\
\hline $\begin{array}{l}\text { Reported as illegally logged or } \\
\text { laundered }\end{array}$ & Illegal logging reported frequently & $\begin{array}{l}\text { Illegal harvesting reported in protected } \\
\text { forest }^{\mathrm{a}}\end{array}$ \\
\hline Timber status (protected or not) & Not protected & $\begin{array}{l}\text { Not protected in Indonesia, but listed in } \\
\text { Appendix II of CITES }\end{array}$ \\
\hline $\begin{array}{l}\text { Area distribution (widespread or } \\
\text { concentrated) }\end{array}$ & Widespread (Java, Sumatra, Sulawesi) & $\begin{array}{l}\text { Widespread (Java, East Nusa Tenggara, } \\
\text { Sumbawa) }\end{array}$ \\
\hline Physically easy to access & Yes, found in nonstate and state forests & Yes, found in nonstate and state forests \\
\hline Abundant or rare & Abundant & Quite rare \\
\hline $\begin{array}{l}\text { Dangerous to access for wood } \\
\text { sample collection }\end{array}$ & No & No \\
\hline Natural/plantation species & Plantation ${ }^{b}$ & Plantation ${ }^{b}$ \\
\hline
\end{tabular}

Notes: CITES = Convention on International Trade in Endangered Species of Wild Fauna and Flora.

a. Based on Rosary (2018).

b. Naturally grown species are more preferable because plantation species are artificially distributed and will create confusion about origin.

Source: WRI authors. 
However, some tools, such as stable isotope and DNA analysis, are not able to get rapid results because they require a relatively longer time for analysis. Thus, it would be burdensome to try to apply these technologies at checkpoints. Other tools, such as NIRS and DARTTOFMS, do provide rapid analysis, but their large size makes them impractical in the field. Machine vision tools such as AIKO and the XyloTron, are preferable for immediate results since they only require a handheld identifier with moderately mobile tools, such as a mobile phone and laptop. Thus, wood ID tools are only one piece of the effort to combat illegal logging, and traceability tools that have been used by the government, such as documents, electronic tracking, barcodes, and so forth, are still important and need continuous improvement.

Considering the practicability of these tools, officials will need to distinguish between "screening" and "forensic validation" tools. Screening tools, such as AIKO and the XyloTron, are better suited for field-checking purposes used by customs officers and forest rangers, but they can be less accurate compared to other techniques and analyses. However, for quick results on the ground, those tools are quite useful to preliminarily identify any documentation fraud at checkpoints that could be a sign of illegal timber trading. Complete "forensic validation" analyses and techniques (DNA analysis, stable isotope analysis, DART-TOFMS, and NIRS) are required for proving illegal logging cases. Developing a protocol for illegal timber investigations at checkpoints as well as in court cases would prove the value of wood ID technologies in combating illegal logging crimes. 


\section{APPENDIX A: INTERVIEWS AND CORRESPONDENCE}

Interviews were conducted with six types of experts (Table A1).

Table A1. | People Interviewed for This Study

\begin{tabular}{|l|l|l|}
\hline INTERVIEWEE & INSTITUTION & EXPERTISE \\
\hline Wood scientist & BIOTIFOR, Yogyakarta & Forest genetics \\
\hline Laboratory staff & Customs Office (Kantor Bea Cukai) & $\begin{array}{l}\text { Identification of goods, including timber } \\
\text { products }\end{array}$ \\
\hline Staffa & Double Helix Tracking Technologies, Singapore & Chain of custody and timber tracking \\
\hline Wood anatomy researcher & Forest and Environment Research, Development and & Wood anatomy and identification \\
\hline Businessman & Innovation Agency (FORDA), Ministry of Environment and & \\
\hline Wood scientist & Forestry & \\
\hline Wood scientist & Association of Indonesian Forest Businessmen (Asosiasi & Business \\
\hline Local civil society organizations ${ }^{b}$ & Pengusaha Hutan Indonesia) & Auriga and the Independent Forest Monitoring Network \\
\hline Staff & Institut Pertanian Bogor (IPB) University & Forest monitoring \\
\hline
\end{tabular}

Notes: All interviews were in-person interviews, except where otherwise indicated.

a. Online interview.

Source: WRI authors

The following questions were posed to the experts:

From your experience, how do wood ID technologies help to identify timber species or origin? How accurate are these technologies to generate that information?

What are the limitations of these technologies?

- Do you have any notable experiences working on illegal logging cases?

- How advanced is your laboratory in conducting wood analysis? What kind of capacities do you already have in your laboratory?
What are some enabling conditions for the use of these technologies?

For the businessman: could you explain how the electronic system works for harvesting in state forests?

- For local civil society organizations: are you aware of wood ID technologies? Have you used these technologies? 
AIKO

APL

BIOTIFOR

BKSDA

CITES

DART-TOFMS

Dirjen PHPL

Dirjen KSDAE

DKP

DNA

FAO

FLEGT

FORDA

FSC

ID

IPB
Alat Identifikasi Kayu Otomatis (Automatic Wood Identification Tool)

areal penggunaan lain (other-use forest)

Balai Besar Penelitian dan Pengembangan

Bioteknologi dan Pemuliaan Tanaman Hutan

(Center for Forest Biotechnology and Tree

Improvement)

Balai Konservasi Sumber Daya Alam (Office of Natural Resources Conservation)

Convention on International Trade in Endangered Species of Wild Fauna and Flora

direct analysis in real time (time of flight) mass spectrometry

Direktorat Jendral Pengelolaan Hutan Produksi Lestari (Directorate General of Sustainable Production Forest Management)

Direktorat Jenderal Konservasi Sumber Daya Alam dan Ekosistem (Directorate General of Natural Resources and Ecosystem Conservation)

Deklarasi Kesesuaian Pemasok (Supplier's Declaration of Conformity)

deoxyribonucleic acid

Food and Agriculture Organization of the United Nations

Forest Law Enforcement, Governance, and Trade

Forest and Environment Research, Development and Innovation Agency

Forest Stewardship Council

identification

Institut Pertanian Bogor University
IPPKH

Izin Pinjam Pakai Kawasan Hutan (Borrow-to-Use Permit)

IUPHHK-HA Izin Usaha Pemanfaatan Hasil Hutan Kayu-Hutan Alam (selective logging forest concession)

IUPHHK-HTI Izin Usaha Pemanfaatan Hasil Hutan Kayu-Hutan Tanaman Industri (timber plantation)

IUPHHK-RE Izin Usaha Pemanfaatan Hasil Hutan KayuRestorasi Ekosistem (ecosystem restoration)

LIPI

Lembaga IImu Pengetahuan Indonesia (Indonesian Institute of Science)

MoEF

Ministry of Environment and Forestry

NIRS

PEFC

$\mathrm{PSDH}$

RKU

RKT

SATS-DN

SATS-LN

SIPUHH

S-LK

SVLK

VPA near-infrared spectroscopy

Programme for the Endorsement of Forest Certification

Provisi Sumberdaya Hutan (Forest Resource Provision)

Rencana Kerja Umum (General Work Plan)

Rencana Kerja Tahunan (Annual Work Plan)

Surat Angkut Tanaman dan Satwa Dalam Negeri (Domestic Transport of Plants and Animals Letter)

Surat Angkut Tanaman dan Satwa Luar Negeri (Overseas Transport of Plants and Animals Letter)

Sistem Informasi Penatausahaan Hasil Hutan (Administration of Forest Information System)

Sertifikasi Legalitas Kayu (Timber Legality Certification)

Sistem Verifikasi Legalitas Kayu (Timber Legality Assurance System)

voluntary partnership agreement 


\section{ENDNOTES}

1. The EU FLEGT program aims to ensure that timber products entering the European Union are legally harvested, processed, and traded. One of its main activities is building relationships with timberproducing countries, such as Indonesia, through bilateral VPAs. A VPA commits timber-producing countries to adopt timber legality assurance systems in their countries in exchange for access to the EU timber market.

2. Based on an interview with the chief executive officer of Double Helix Tracking Technologies, January 17, 2018. 
Abe, H., A. Hayano, and M. Inoue-Murayama. 2012. "Forensic Species Identification of Large Macaws Using DNA Barcodes and Microsatellite Profiles." Molecular Biology Reports 39 (1): 693-99. https://doi.org/10.1007/ s11033-011-0787-1.

Apriando, T. 2013. "Pengelolaan Hutan di Jawa oleh Perhutani Dinilai Gagal Sejahterakan Masyarakat." Mongabay, January 28. https://www. mongabay.co.id/2013/01/28/pegelolaan-hutan-di-jawa-oleh-perhutanidinilai-gagal-sejahterakan-masyarakat/.

Asrida, E. 2018. "Dokumen Palsu Kayu-kayu dari Hutan Nabire." Mongabay, August 18. https://www.mongabay.co.id/2018/08/31/dokumen-palsukayu-kayu-dari-hutan-nabire/.

Auriga. 2017. "Pelanggaran SVLK: Koalisi Anti Mafia Hutan Adukan 7 Perusahaan Penggergajian Kayu di Papua." November 28. http://archive. is/BgK4H..

Blanc-Jolivet, C., Y. Yanbaev, B. Kersten, and B. Degen. 2018. "A Set of SNP Markers for Timber Tracking of Larix spp. in Europe and Russia." Forestry 91 (5): 614-28. https://doi.org/10.1093/forestry/cpy020.

Cao, C.P., O. Gailing, I.Z. Siregar, U.J. Siregar, and R. Finkeldey. 2009. "Genetic Variation in Nine Shorea Species (Dipterocarpaceae) in Indonesia Revealed by AFLPs." Tree Genetics \& Genomes 5 (3): 407-20. https://doi.org/10.1007/s11295-008-0195-4.

Carlquist, S. 2001. Comparative Wood Anatomy: Systematic, Ecological, and Evolutionary Aspects of Dicotyledon Wood. 2nd ed. Berlin: SpringerVerlag.

CITES (Convention on International Trade in Endangered Species of Wild Fauna and Flora). 2021. "Appendices." February 14. https://cites.org/eng/ app/appendices.php.

Clemento, A.J., E.D. Crandall, J.C. Garza, and E.C. Anderson. 2014. "Evaluation of a Single Nucleotide Polymorphism Baseline for Genetic Stock Identification of Chinook Salmon (Oncorhynchus tshawytscha) in the California Current Large Marine Ecosystem." Fishery Bulletin 112 (2-3): 112-30. https://doi.org/10.7755/FB.112.2-3.2.

Damayanti, R. 2018. "Identifikasi Kayu Melalui Aplikasi." Forest Digest, October-December. https://www.forestdigest.com/detail/157/identifikasikayu-melalui-aplikasi.

Degen, B., S.E. Ward, M.R. Lemes, C. Navarro, S. Cavers, and A.M. Sebbenn. 2013. "Verifying the Geographic Origin of Mahogany (Swietenia macrophylla King) with DNA-Fingerprints." Forensic Science International: Genetics 7 (1): 55-62. https://doi.org/10.1016/j.fsigen.2012.06.003.

Directorate of Biodiversity Conservation. 2017. Information of the Conservation Status, Management and Trade of Dalbergia Latifolia in Indonesia. Jakarta: Directorate of Biodiversity Conservation, Ministry of Environment and Forestry, Government of Indonesia. https:// ec.europa.eu/transparency/regexpert/index.cfm?do=groupDetail. groupDetailDoc\&id=35079\&no=9.
Dormontt, E.E., M. Boner, B. Braun, G. Breulmann, B. Degen, E. Espinoza, S. Gardner, et al. 2015. "Forensic Timber Identification: It's Time to Integrate Disciplines to Combat Illegal Logging." Biological Conservation 191 (November): 790-98. https://doi.org/10.1016/j.biocon.2015.06.038.

Double Helix Tracking Technologies. 2018. "Plant DNA Evidence Supports Landmark Lacey Act Conviction of Big Mapleleaf Theft." July 1. https:// www.doublehelixtracking.com/news/2019/2/21/plant-dna-evidencesupports-landmark-lacey-act-conviction-of-bigleaf-maple-theft.

EIA (Environmental Investigation Agency). 2013. Liquidating the Forests: Hardwood Flooring, Organized Crime and the World's Last Siberian Tigers. London: EIA. https://content.eia-global.org/posts/ documents/000/000/609/original/ElA_Liquidating_the_Forests. pdf?1479504214.

Erickson-Davis, M. 2017. "Major Dutch Timber Company Found Guilty of Dealing in Illegal Teak." Mongabay, November 2. https://news.mongabay. com/2017/11/major-dutch-timber-company-found-guilty-of-dealing-inillegal-teak/

Espinoza, E.0., M.C. Wiemann, J. Barajas-Morales, G.D. Chavarria, and P.J. McClure. 2015. "Forensic Analysis of CITES-Protected Dalbergia Timber from the Americas." IAWA Journal 36 (3): 311-25. https://doi. org/10.1163/22941932-20150102.

EU FLEGT (European Union Forest Law Enforcemnt, Governance, and Trade) Facility. 2019. Small and Micro-Sized Entities in the Mekong Region's Forest Sector: A Situational Analysis in the FLEGT Context. Barcelona: EU FLEGT Facility. http://www.euflegt.efi.int/documents/10180/467581/ SmEs++in+the+Mekong+region+forest+sector-+situational+analysis. pdf/081bcea0-89db-100d-e443-2239005edf95.

Evans, P.D., I.A. Mundo, M.C. Wiemann, G.D. Chavarria, P.J. McClure, D. Voin, and E.0. Espinoza. 2017. "Identification of Selected CITES-Protected Araucariaceae Using DART TOFMS." IAWA Journal 38 (2): 266-81. https:// doi.org/10.1163/22941932-20170171.

FA0 (Food and Agriculture Organization of the United Nations). 2016. "Traceability: A Management Tool for Enterprises and Governments." Technical Paper 1. Rome: FLEGT Programme, FA0, http://www.fao.org/3/ai6134e.pdf.

FAO and UNEP (United Nations Environment Programme), 2020. The State of the World's Forests 2020: Forests, Biodiversity and People. Rome: FA0. http://www.fao.org/state-of-forests/en/.

Ferri, G., M. Alù, B. Corradini, and G. Beduschi. 2009. "Forensic Botany: Species Identification of Botanical Trace Evidence Using a Multigene Barcoding Approach." International Journal of Legal Medicine 123 (5): 395-401. https://doi.org/10.1007/s00414-009-0356-5.

Finch, K., E. Espinoza, F.A. Jones, and R. Cronn. 2017. "Source Identification of Western Oregon Douglas-Fir Wood Cores Using Mass Spectrometry and Random Forest Classification." Applications in Plant Sciences 5 (5): 1600158. https://doi.org/10.3732/apps.1600158. 
Finch, K.N., R.C. Cronn, M.C.A. Richter, C. Blanc-Jolivet, M.C.C. Guerrero, L. De Stefano Beltrán, C.R. García-Dávila, et al. 2020. "Predicting the Geographic Origin of Spanish Cedar (Cedrela odorata L.) based on DNA Variation." Conservation Genetics 21 (4): 625-39. https://doi.org/10.1007/ s10592-020-01282-6.

Förstel, H., M. Boner, A.M. Höltke, M. Fladung, B. Degen, and J. Zahnen. 2011. Fighting Illegal Logging through the Introduction of a Combination of the Isotope Method for Identifying the Origins of Timber and DNA Analysis for Differentiation of Tree Species. Project Report. Berlin: WWF Germany.

Galpern, P., M. Manseau, P. Hettinga, K. Smith, and P. Wilson. 2012. "ALLELEMATCH: An R Package for Identifying Unique Multilocus Genotypes Where Genotyping Error and Missing Data May Be Present." Molecular Ecology Resources 12 (4): 771-78. https://doi.org/10.1111/j.17550998.2012.03137.x.

Hartvig, I., M. Czako, E.D. Kjaer, L.R. Nielsen, and I. Theilade. 2015. "The Use of DNA Barcoding in Identification and Conservation of Rosewood (Dalbergia spp.)." PLoS ONE 10 (9): e0138231. https://doi.org/10.1371/journal. pone.0138231.

Hassold, S., P.P. Lowry, M.R. Bauert, and A. Razafintsalama. 2016. "DNA Barcoding of Malagasy Rosewoods: Towards a Molecular Identification of CITES-Listed Dalbergia Species." PLoS ONE 11 (6): 1-17. https://doi. org/10.1371/journal.pone.0157881.

Hermanson, J.C., and A.C. Wiedenhoeft. 2011. "A Brief Review of Machine Vision in the Context of Automated Wood Identification Systems." IAWA Journal 32 (2): 233-50. https://doi.org/10.1163/22941932-90000054.

Hoadley, R.B. 2000. Understanding Wood: A Craftsman's Guide to Wood Technology. Newtown, CT: Taunton.

Hoare, A. 2015. Tackling Illegal Logging and the Related Trade: What Progress and Where Next? London: Chatham House. https://www. chathamhouse.org/sites/default/files/publications/research/20150715Ille galLoggingHoareFinal.pdf.

Ichwan, M., S. Hermawan, K. Sugianto, M. Kosar, and D.T. Ferdiyan. 2017. 7 Tahun Memantau Industri Pengolahan Kayu Hasil Pemantauan Sistem Verifikasi Legalitas Kayu (SVLK) di Provinsi Jawa Timur Periode 2011-2017. East Java: Pusat Pendidikan Lingkungan Hidup Mangkubumi. https:// pplh-mangkubumi.or.id/2018/03/09/publikasi-buku-7-tahun-memantauindustri-pengolahan-kayu/.

Jong, H.N. 2019. "In Indonesia, a Flawed Certification Scheme Lets Illegal Loggers Raze Away." Mongabay, May 16 . https://news.mongabay. com/2019/05/in-indonesia-a-flawed-certification-scheme-lets-illegalloggers-raze-away/.

Julian, R., S. Kelty, and J. Robertson. 2018. "'Get It Right the First Time': Critical Issues at the Crime Scene." Current Issues in Criminal Justice 24 (1): 25-37. https://doi.org/10.1080/10345329.2012.12035942.

Karlinasari, L., M. Sabed, I.N.J. Wistara, and Y.A. Purwanto. 2014. "Near infrared (NIR) Spectroscopy for Estimating the Chemical Composition of (Acacia mangium Willd.) Wood." Journal of the Indian Academy of Wood Science 11 (December): 162-67. https://doi.org/10.1007/s13196-014-0133-z.
Kitpipit, T., S.S. Tobe, A.C. Kitchener, P. Gill, and A. Linacre. 2012. "The Development and Validation of a Single SNaPshot Multiplex for Tiger Species and Subspecies Identification-Implications for Forensic Purposes." Forensic Science International: Genetics 6 (2): 250-57. https:// doi.org/10.1016/j.fsigen.2011.06.001.

Lancaster, C., and E. Espinoza. 2012. "Analysis of Select Dalbergia and Trade Timber Using Direct Analysis in Real Time and Time-of-Flight Mass Spectrometry for CITES Enforcement." Rapid Communincations in Mass Spectrometry 26 (February): 1147-56. https://doi.org/10.1002/rcm.6215.

Lee, S., B.S. Park, D. Lee, H. Chung, and K.-S. Lee. 2015. "Spatial Variability in Hydrogen and Oxygen Isotopic Composition of Korean Red Pine and Its Implication for Tracing Wood Origin." Environmental Earth Sciences 73 (June): 8045-52. https://doi.org/10.1007/s12665-014-3960-8.

Lee, S.Y., W.L. Ng, M.N. Mahat, M. Nazre, and R. Mohamed. 2016. "DNA Barcoding of the Endangered Aquilaria (Thymelaeaceae) and Its Application in Species Authentication of Agarwood Products Traded in the Market." PLOS ONE 11 (4): 1-21. https://doi.org/10.1371/journal.pone.0154631.

Liu, F., K. Wheiler, I. Ganguly, and M. Hu. 2020. "Sustainable Timber Trade: A Study on Discrepancies in Chinese Logs and Lumber Trade Statistics." Forests 11 (2): 205. https://doi.org/10.3390/f11020205.

Lowe, A.J., and H.B. Cross. 2011. "The Application of DNA Methods to Timber Tracking and Origin Verification." IAWA Journal 32 (2): 251-62. https://doi. org/10.1163/22941932-90000055.

Lowe, A.J., K.-N. Wong, Y.-S. Tiong, S. lyerh, and F.T. Chew. 2017. "A DNA Method to Verify the Integrity of Timber Supply Chains: Confirming the Legal Sourcing of Merbau Timber from Logging Concession to Sawmill." Silvae Genetica 59 (1-6). https://doi.org/10.1515/sg-2010-0037.

Neumeister, C., and S. Cooper. 2019. Money Tree: Teak and Conflict in South Sudan. Washington, DC: Center for Advanced Defense Studies. https:// c4ads.org/money-tree.

Ng, C.H., S.L. Lee, L.H. Tnah, K.K.S. Ng, C.T. Lee, B. Diway, and E. Khoo. 2017. "Geographic Origin and Individual Assignment of Shorea platyclados (Dipterocarpaceae) for Forensic Identification." PLOS ONE 12 (April): 1-18. https://doi.org/10.1371/journal.pone.0176158.

Ng, K.K.S., S.L. Lee, L.H. Tnah, Z. Nurul-Farhanah, C.H. Ng, C.T. Lee, N. Tani, et al. 2016. "Forensic Timber Identification: A Case Study of a CITES Listed Species, Gonystylus bancanus (Thymelaeaceae)." Forensic Science International: Genetics 23 (July): 197-209. https://doi.org/10.1016/j. fsigen.2016.05.002.

Obidzinski, K, A. Dermawan, A. Andrianto, H. Komarudin, and D. Hernawan 2014. "Timber Legality Verification and Small-Scale Forestry Enterprises in Indonesia: Lessons Learned and Policy Options." Infobrief 76. Bogor: Center for International Forestry Research. https://www.cifor.org/ knowledge/publication/4862/.

Ogden, R., K. Gharbi, N. Mugue, J. Martinsohn, H. Senn, and J.W. Davey. 2013. "Sturgeon Conservation Genomics: SNP Discovery and Validation Using RAD Sequencing." Molecular Ecology 22 (11): 3112-23. https://doi. org/10.1111/mec.12234. 
Ogden, R., H.N. McGough, R.S. Cowan, L. Chua, M. Groves, and R. McEwing. 2008. "SNP-Based Method for the Genetic Identification of Ramin Gonystylus spp. Timber and Products: Applied Research Meeting CITES Enforcement Needs." Endangered Species Research 9 (3): 255-61. https:// doi.org/10.3354/esr00141

Paredes-Villanueva, K., C. Blanc-Jolivet, M. Mader, E.N.H. Coronado, C. Garcia-Davila, A.M. Sebbenn, B.R.V. Meyer-Sand, et al. 2020. "Nuclear and Plastid SNP Markers for Tracing Cedrela Timber in the Tropics." Conservation Genetics Resources 12 (June): 239-44. https://doi. org/10.1007/s12686-019-01110-1.

Pastore, T.C.M., J.W.B. Braga, V.T.R. Coradin, W.L.E. Magalhães, E.Y.A. Okino, J.A.A. Camargos, G.I. Bonzon de Muñiz, O.A. Bressan, and F. Davrieux. 2011. "Near Infrared Spectroscopy (NIRS) as a Potential Tool for Monitoring Trade of Similar Woods: Discrimination of True Mahogany, Cedar, Andiroba, and Curupixá." Holzforschung 65 (1): 73-80. https://doi. org/10.1515/HF.2011.010.

Ritonga, F.N., F.G.U.S. Dwiyanti, C. Kusmana, U.J. Siregar, and I.Z. Siregar. 2018. "Population Genetics and Ecology of Sumatran Camphor (Dryobalanops aromatica) in Natural and Community-Owned Forests in Indonesia." Biodiversitas 19 (6): 2175-82. https://doi.org/10.13057/biodiv/ d190625.

Rosary, E.D. 2018. "Kisruh Dugaan Pembalakan Liar Kayu Sonokeling di NTT, Bagaimana Akhirnya?", Mongabay, October 17. https://www. mongabay.co.id/2018/10/17/kisruh-dugaan-pembalakan-liar-kayusonokeling-di-ntt-bagaimana-akhirnya/.

Siregar, E.B.M. 2005. "Potensi Budidaya Jati." Medan, Indonesia: University of Sumatera Utara. http://repository.usu.ac.id/ bitstream/handle/123456789/999/hutan-edi batara10. pdf? sequence=1\&isAllowed=y.

Sonsin, J.0., P.E. Gasson, C.F. Barros, and C.R. Marcati. 2012. "A Comparison of the Wood Anatomy of 11 Species from Two Cerrado Habitats (Cerrado s.s. and Adjacent Gallery Forest)." Botanical Journal of the Linnean Society 170 (2): 257-76. https://doi.org/10.1111/j.1095-8339.2012.01282.x.

Suprapto, E. 2010. "Hutan Rakyat: Aspek Produksi, Ekologi dan Kelembagaan." Presented at the National Seminar on the Contribution to Reducing Carbon Emissions from Forest Areas Managed by the Community in a Sustainable and Sustainable Manner, Jakarta, July 29. https://arupa.or.id/hutan-rakyat-2/.
Taylor, V., K. Kecse-Nagy, and T. Osborn. 2012. Trade In Dalbergia nigra and the European Union. Brussels: European Commission. https://ec.europa. eu/environment/cites/pdf/Dalbergia Report_FIN 2012 2012.pdf.

Telapak and EIA (Environmental Investigation Agency). 2005. The Last Frontier: Illegal Logging in Papua and China's Massive Timber Theft. Bogor: Telapak, and London: ElA. https://content.eia-global.org/posts/ documents/000/000/413/original/The_Last_Frontier.pdf?1468421007.

Tempo. 2018. "Mesin Cuci Kayu Ilegal." December 21. https://majalah. tempo.co/read/156815/mesin-cuci-kayu-ilegal.

Tnah, L.H., S.L. Lee, K.K.S. Ng, Q.-Z. Faridah, and I. Faridah-hanum. 2010. "Forest Ecology and Management Forensic DNA Profiling of Tropical Timber Species in Peninsular Malaysia." Forest Ecology and Management 259 (8): 1436-46. https://doi.org/10.1016/j.foreco.2010.01.017.

Tsuchikawa, S., K. Inoue, and J. Noma. 2003. "Application of Near-Infrared Spectroscopy to Wood Discrimination." Journal of Wood Science 49 (February): 29-35. https://doi.org/10.1007/s100860300005.

Wasser, S.K., A.M. Shedlock, K. Comstock, E.A. Ostrander, B. Mutayoba, and M. Stephens. 2004. "Assigning African Elephant DNA to Geographic Region of Origin: Applications to the Ivory Trade." Proceedings of the National Academy of Sciences of the United States of America 101 (41): 14847-52. https://doi.org/10.1073/pnas.0403170101.

Wheeler, E.A. 2011. "InsideWood: A Web Resource for Hardwood Anatomy." IAWA Journa/ 32 (2): 199-211. https://doi.org/10.1163/22941932-90000051.

Wimmer, R., and M. Grabner. 1997. "Effects of Climate on Vertical Resin Duct Density and Radial Growth of Norway Spruce [Picea abies (L.) Karst.]." Trees 11 (April): 271-76. https://link.springer.com/article/10.1007/ PL00009673.

Yang, Z., Y. Liu, X. Pang, and K. Li. 2015. "Preliminary Investigation into the Identification of Wood Species from Different Locations by Near Infrared." BioResources 10 (4): 8505-17. https://ojs.cnr.ncsu.edu/index.php/BioRes/ article/view/BioRes_10_4_8505_Yang_Preliminary_Investigation_ Wood_Species_Infrared/3958.

Yuwono, T., and T. Listyanto. 2017. "Analisis Daya Saing Industri Kecil dan Menengah Berbasis Bahan Baku Hutan Rakyat dalam Menghadapi Era Sertifikasi: Studi Kasus di Yogyakarta dan Jepara." In Hutan Rakyat di Simpang Jalan, edited by A. Maryudi and A.A. Nawir, 151. Yogyakarta, Indonesia: Gadjah Mada University Press. 


\section{ACKNOWLEDGMENTS}

The field work in Yogyakarta Province and Klaten District in Central Java Province was carried out with the help of the Aliansi Relawan Untuk Penyelamatan Alam (Arupa), a local NGO based in Yogyakarta.

The authors thank WRI's Forest Legality Initiative team, the Research Data Innovation (RDI) team, and all the reviewers for their support in completing this study. Thanks also to all of the interviewed respondents for their help and cooperation.

\section{ABOUT THE AUTHORS}

Kenny Cetera is a forest legality analyst at WRI Indonesia.

Contact: kenny.cetera@wri.org.

Zuraidah Said is a Global Forest Watch coordinator at WRI Indonesia.

Contact: zuraidah.said@wri.org

Febrina Dellarose Boer is a former researcher at WRI Indonesia and currently a researcher at the French Agricultural Centre for International Development (CIRAD).

Contact: dellarose.db@gmail.com

Indira Nurul Qomariah is a former researcher at WRI Indonesia and currently a biology advisor at the Centre for Orangutan Protection.

Contact: qomariahindira@gmail.com

Edi Suprapto is the Executive Director of Yayasan Arupa.

Contact: edisuprapto@gmail.com

Sugeng Triyanto is a researcher at Yayasan Arupa.

Contact: comer_rasul@yahoo.com 


\section{ABOUT WRI}

World Resources Institute Indonesia is an independent research organization that turns big ideas into action at the nexus of environment, economic opportunity, and human well-being.

\section{Our Challenge}

Natural resources are at the foundation of economic opportunity and human well-being. But today, we are depleting Earth's resources at rates that are not sustainable, endangering economies and people's lives. People depend on clean water, fertile land, healthy forests, and a stable climate. Livable cities and clean energy are essential for a sustainable planet. We must address these urgent, global challenges this decade.

\section{Our Vision}

We envision an equitable and prosperous planet driven by the wise management of natural resources. We aspire to create a world where the actions of government, business, and communities combine to eliminate poverty and sustain the natural environment for all people.

\section{Our Approach}

\section{COUNT IT}

We start with data. We conduct independent research and draw on the latest technology to develop new insights and recommendations. Our rigorous analysis identifies risks, unveils opportunities, and informs smart strategies. We focus our efforts on influential and emerging economies where the future of sustainability will be determined.

\section{CHANGE IT}

We use our research to influence government policies, business strategies, and civil society action. We test projects with communities, companies, and government agencies to build a strong evidence base. Then, we work with partners to deliver change on the ground that alleviates poverty and strengthens society. We hold ourselves accountable to ensure our outcomes will be bold and enduring.

\section{SCALE IT}

We don't think small. Once tested, we work with partners to adopt and expand our efforts regionally and globally. We engage with decision-makers to carry out our ideas and elevate our impact. We measure success through government and business actions that improve people's lives and sustain a healthy environment. 